\title{
Technical note: High accuracy weighing micro-lysimeter system for long-term measurements of non-rainfall water inputs to grasslands
}

\author{
Andreas Riedl ${ }^{1}$, Yafei Li ${ }^{1}$, Nina Buchmann ${ }^{1}$, Werner Eugster ${ }^{1}$ \\ ${ }^{1}$ Department of Environmental Systems Science, ETH Zurich, Zurich, 8092, Switzerland
}

5 Correspondence to: Andreas Riedl (andreas.riedl@usys.ethz.ch)

\begin{abstract}
Non-rainfall water (NRW), defined here as dew, hoar frost, fog, rime and water vapor adsorption, might be a relevant water source for ecosystems, especially during summer drought periods. These water inputs are often not considered in ecohydrological studies, because water amounts of NRW events are rather small and therefore difficult to measure. Here we present a novel micro-lysimeter (ML) system and its application which allows to quantify very small water inputs from

10 NRW with an unprecedented high accuracy of $\pm 0.25 \mathrm{~g}$, which corresponds to $\pm 0.005 \mathrm{~mm}$ water input. This is possible with an improved ML design paired with individual ML calibrations in combination with high-frequency measurements at $3.3 \mathrm{~Hz}$ and an efficient low-pass filtering to reduce noise level. With a set of ancillary sensors, the ML system furthermore allows differentiating between different types of NRW inputs: dew, hoar frost, fog, rime and the combinations among these, but also additional events when condensation on leaves is less probable, such as water vapor adsorption events. In addition, our ML system design allows to minimize deviations from natural conditions in terms of canopy and soil temperatures, plant growth and soil moisture. This is found to be a crucial aspect for obtaining realistic NRW measurements in short-statured grasslands. Our ML system has proven to be useful for high-accuracy, long-term measurements of NRW on short-statured vegetation like grasslands. Measurements with the ML system at a field site in Switzerland showed that NRW input occurred frequently with 127 events over 12 months, with a total NRW input of $15.9 \mathrm{~mm}$. High average monthly NRW inputs were measured during summer months, suggesting a high ecohydrological relevance of NRW inputs for temperate grasslands.
\end{abstract}

\section{Introduction}

Non-rainfall water (NRW) inputs, defined here as dew, hoar frost, fog, rime and water vapor adsorption, provide water to plants. These different inputs form under different environmental conditions: Dew forms on plant surfaces when the temperature of the surface drops below the dewpoint temperature of

25 the adjacent air (Beysens, 2018; Monteith, 1957), whereas dew forming directly on soil surfaces is rarely observed (Agam and Berliner, 2004; Ninari and Berliner, 2002). In addition, hoar frost is frozen dew, which forms at temperatures below $0{ }^{\circ} \mathrm{C}$. Fog droplets form on condensation nuclei (aerosol particles) in the atmosphere when water vapor concentration reaches saturation, while rime is supercooled fog in contact with a surface (e.g. vegetation) at a temperature below $0{ }^{\circ} \mathrm{C}$. Water vapor

30 adsorption occurs on hygroscopic surfaces, which can lower saturation vapor pressure and thus lead to 
adsorption, despite the fact that temperatures are still above dewpoint temperature (Agam and Berliner, 2006; McHugh et al., 2015). However, these water inputs are generally ignored in ecosystems that receive ample water by rainfall, namely in climates where rainfall exceeds evapotranspiration in the annual budget. Here we present the design of a novel micro-lysimeter (ML) system with improved accuracy that was deployed at a Swiss mountain site (982 m elevation) where rainfall exceeds evaporation in average years. Prolonged drought periods can occur even under such climatic conditions and are expected to increase by 1 to 9 days by 2085 (with RCP8.5, compared to the reference period 1980-2010) (Fischer and Schär, 2018). During drought periods, when rainfall input is absent, NRW can be the only available atmospheric water source. Thus, we hypothesize that NRW inputs to plants

40 constitute an important water source during drought periods, even under temperate climate conditions with ample average rainfall. It remains to be investigated whether the frequency and amount of NRW inputs are also high in summer. Groh et al. (2018) for example found that NRW inputs were on average higher in autumn and winter months, i.e. from October until February. However, at another temperate site the second highest average NRW input was found in May. In general, higher NRW inputs and

45 higher frequency of NRW inputs are expected to occur during spring, autumn and winter, when nights are longer than in summer, and when there is a higher probability for NRW inputs to occur. Thus, longterm measurements are important to observe such seasonal NRW input patterns and will allow to investigate the potential effects of NRW inputs on grasslands during the main vegetation period in summer. Here we present an improved method that is suitable for automated long-term measurements of NRW inputs to short-statured grassland vegetation during dry spells and drought periods.

NRW inputs can have a significant influence on plant water relations by increasing plant water status (Boucher et al., 1995; Kerr and Beardsell, 1975; Wang et al., 2019; Yates and Hutley, 1995) and plant water content (Limm et al., 2009; Munné-Bosch and Alegre, 1999). Plants can take up NRW via the leaves termed as foliar water uptake (Berry et al., 2014; Eller et al., 2013; Slatyer, 1960), or via the

55 roots (Wang et al., 2019). NRW is brought to the rhizosphere by drip-off from leaves and stems (Dawson, 1998), or by dew formation and/or fog droplet interception and impaction on soils (Agam and Berliner, 2006; Kaseke et al., 2012; Uclés et al., 2013). Moreover, NRW can also reduce water loss (1) by suppressing transpiration (Aparecido et al., 2016; Gerlein-Safdi et al., 2018; Ishibashi and Terashima, 1995; Waggoner et al., 1969), induced by clogged stomata (Gerlein-Safdi et al., 2018;

60 Vesala et al., 2017); (2) by reducing the vapor pressure deficit (Ritter et al., 2009) in the boundary layer between leaves and the atmosphere; and (3) by decreasing canopy temperatures because of evaporative cooling during re-evaporation of NRW inputs (Thornthwaite, 1948). The energy from incoming solar radiation is partially used for the phase transition from liquid water to water vapor, which thereby alleviates potential heat stress of the plants. Moreover, canopy temperature may decrease due to an

65 increase in surface albedo (Eugster et al., 2006; Minnis, 1997), when more light is reflected as long as the surface is wet. NRW might also influence plant water relations via these micro-environmental effects in periods and climates when soil water availability is not a limiting factor for plant growth. Thus, quantifying NRW inputs in different climates is considered to be of high relevance now and in the future.

70 Despite these significant effects of NRW on plant water relations, NRW inputs are the least studied component in ecohydrology (Wang et al., 2019), because NRW inputs are difficult to quantify (Groh et al., 2018; Jacobs et al., 2006; Kidron and Starinsky, 2019). High accuracy measurement 
instrumentation, which simulates natural conditions, e.g. in terms of surface properties, while minimizing disturbances, is required to capture the comparatively small water inputs. There exists no international agreement on a reference standard instrumentation system for NRW measurements (Chen et al., 2005; Groh et al., 2018). Over the last decades, different measurement systems were developed (see Kidron and Starinsky, 2019). Lysimeter (LM) and ML systems simulate natural conditions well (Ninari and Berliner, 2002) and are therefore considered as accurate and reliable NRW measurement methods (Ninari and Berliner, 2002; Richards, 2004; Uclés et al., 2013). Hence, they became the most commonly used methods over the last decades (Kidron and Starinsky, 2019). LM differ from ML by their much larger size, although there is no well-defined size threshold that indisputably allows to separate LM from ML (6 to $25 \mathrm{~cm}$ in diameter and 3.5 to $25 \mathrm{~cm}$ in depth). Most ML systems were developed for application in arid regions to measure NRW inputs to soils and sand. ML systems for temperate regions may have different requirements, because quantification of NRW inputs on

85 vegetation requires a sufficient ML size for natural plant (root) growth. ML with shallow depth and small radius can alter normal plant (root) growth, because of insufficient space availability. This characteristic makes them unsuitable for long-term NRW studies on vegetation with a high demand for root space. Furthermore, natural soil-atmosphere water exchange might be altered by shallow depth of the ML in some ecosystems. While limited rainfall retention capacity of ML is not a problem for NRW quantification, the potential prevention of upward direct water flow due to capillary rise from deeper soil layers cannot be neglected (Evett et al., 1995), because it replenishes plant available water in the rooting zone. Likewise, the energy budget of small ML can be severely affected by its insufficient depth (Kidron and Kronenfeld, 2017; Ninari and Berliner, 2002). All LM and ML are disconnected from the surrounding soil and therefore can exhibit a more efficient heat loss via nocturnal long-wave radiative cooling (Kidron and Kronenfeld, 2017). To accurately measure NRW inputs on short-statured vegetation it is thus crucial that the canopy temperature of the ML vegetation equals the canopy temperature in its surrounding (control). This is especially true for dew formation, hoar frost and water vapor adsorption events. Higher temperatures of ML canopies would lead to underestimated NRW amounts, while lower temperatures would lead to overestimated NRW amounts (Kidron and

100 Kronenfeld, 2017). Consequently, measuring NRW inputs reliably needs to take these effects into account.

Our goal was to design and test a ML system for NRW quantification to grasslands in the field, that overcomes drawbacks of existing small ML systems in terms of hampered plant growth and altered canopy and soil temperatures compared to the control (surrounding area). The main drawback of large ML for NRW studies is the tradeoff between weighing capacity and weighing accuracy. The weighing capacity of LM and ML is determined by their load cell capacity: the higher the weighing capacity, the lower the weighing accuracy. In this study, weighing accuracy denotes the difference between the measured mass (determined with a ML) and the control (calibrated mass). Precision reflects the reliability of the measurements, and it specifies to what extent the experiment can be repeated. On the

110 other hand, resolution is the smallest distinguishable unit for an observable change in mass and thus determines the upper limit of precision. For NRW studies, high accuracy is indispensable, which requires instruments with high resolution paired with high precision.

Here, we present a ML system for high accuracy of NRW quantification on short-statured vegetation like grasslands. The main objectives of our study were to: 
(1) develop a ML system with high accuracy that overcomes existing drawbacks of size vs. accuracy and that does not hinder plant growth and does not alter ML temperatures compared to its surroundings.

(2) design a ML system that allows differentiating between different NRW inputs, here defined as dew, hoar frost, fog, rime as well as water vapor adsorption events, and

120 (3) to test for long-term suitability of the ML system in the field and to quantify the share of NRW of the mean annual precipitation.

\section{Material and Methods}

\subsection{Field site Früebüel}

Field work for this study was carried out at Früebüel (CH-FRU), a long-term Swiss FluxNet field site in

125 Switzerland (Pastorello et al., 2020; Zeeman et al., 2010). The site is a permanent grassland site located on a mountain plateau in the Canton of Zug, Switzerland ( $\left.47^{\circ} 06^{\prime} 57.0^{\prime \prime} \mathrm{N}, 8^{\circ} 32^{\prime} 16.0^{\prime \prime} \mathrm{E}\right)$ at an elevation of $982 \mathrm{~m}$ a.s.l.. The annual mean temperature is $7.8^{\circ} \mathrm{C}$ (over a period from 2005 to 2019), the annual mean rainfall is $1232 \mathrm{~mm}(\mathrm{SD}= \pm 372 \mathrm{~mm})$. The site is moderately intensively managed with two to four management events per year, usually a combination of mowing and grazing, depending on

130 vegetation growth (Imer et al., 2013). The dominant species are common ryegrass (Lolium multiflorum), meadow foxtail (Alopecurus pratensis), cocksfoot grass (Dactylis glomerata), dandelion (Taraxacum officinale), buttercup (Ranunculus sp.) and white clover (Trifolium repens) (Sautier, 2007). The main rooting horizon is within the top $20 \mathrm{~cm}$ of soil, with a high root density in the top $11 \mathrm{~cm}$ (Stiehl-Braun et al., 2011).

135 The site is equipped with an agrometeorological station, comprising a temperature and a relative humidity sensor (CS215, Campbell Scientific Inc., Logan, USA) placed in an actively aspired radiation shield, a cup anemometer (A100R, Vector Instruments, North Wales, UK) with a wind vane (W200P, Vector Instruments, North Wales, UK), all installed at a height of $1.15 \mathrm{~m}$, and a 3D anemometer (R350 , Gill Instruments Ltd., Lymington, UK) installed at a height of $1.80 \mathrm{~m}$. Moreover, the site is equipped with a tipping bucket rain gauge $(15188 \mathrm{H}$, Lambrecht meteo $\mathrm{GmbH}$, Goettingen, Germany) and a networked digital camera (NetCam SC, StarDot Technologies, Buena Park, CA, USA). Furthermore, a leaf wetness sensor (PHYTOS 31, Meter Group AG, Munich, Germany) that mimics thermodynamic and radiative properties of a leaf, is installed horizontally at a height of $30 \mathrm{~cm}$, to measure close or in the canopy of the grassland vegetation. A visibility sensor (MiniOFS, Optical

145 sensors Sweden AB, Gothenburg, Sweden) is installed at a height of $1 \mathrm{~m}$ to capture shallow radiation fog and rime events.

\subsection{Methods}

The ML system was composed of three individual ML with additional sensors. The three ML were placed in a row at $1.45 \mathrm{~m}$ intervals. The design of the ML system is presented in Section 2.2.1 - 2.2.8.

150 For better readability, abbreviations for dimensions were used before the corresponding value ( $\mathrm{d}$ for diameter, $\mathrm{h}$ for height or depth, $\mathrm{t}$ for thickness). 


\subsubsection{ML design}

A ML consisted of an outer and an inner part. The outer part (Fig. 1a) was made by a cylindrical PVCU tube (VINK Schweiz GmbH, Dietikon, Switzerland; d45 cm x h42 cm x t0.36 cm) with an open top and a closed bottom. The bottom was closed with a PVC-XT disk (VINK Schweiz GmbH, Dietikon, Switzerland; $\mathrm{d} 46 \mathrm{~cm}, \mathrm{t} 0.3 \mathrm{~cm}$ ), which was welded with a PVC-U welding rod to the cylindrical tube for waterproof closure. The outer part protected the inner part (Fig. 1b-n) from confounding factors like soil pressure, infiltrating water and biota. The core elements of the inner part were a cylindrical pot (Fig. $1 b$ ), filled with a soil monolith (for simplicity called ML pot within this paper) containing the original grass sward. The ML pot was made of a cylindrical PVC-U tube (VINK Schweiz GmbH, Dietikon, Switzerland; d $25 \mathrm{~cm}, \mathrm{~h} 25 \mathrm{~cm}, \mathrm{t} 0.2 \mathrm{~cm}$ ), of which the bottom was closed with a PVC-XT disc (VINK Schweiz GmbH, Dietikon, Switzerland; d26 cm, t0.3 cm) that was welded in the same way as the outer part. The ML pot was mounted on a weighing platform (Fig. 1d-h) by means of three custom made sockets (Fig. 1c), secured with machine screws. The weighing platform consisted mainly of three parts, the load plate (Fig. 1d), a load cell (Fig. 1e), and a base plate (Fig. 1f). The load plate was made of aluminum (AlSilMgMn, d29 cm, t1 cm), likewise the base plate $(\mathrm{d} 35 \mathrm{~cm}, \mathrm{t} 1 \mathrm{~cm})$. Between the load plate and the base plate, a PW15AHY load cell with $20 \mathrm{~kg}$ capacity (HBM, Darmstadt, Germany) was mounted. To allow bending of the load cell, two rectangular spacing washers (Fig. $1 \mathrm{~g}, 2.5 \times 3.1 \mathrm{~cm}, \mathrm{t} 0.1$ $\mathrm{cm}$ ) were mounted between load cell and load plate, and between load cell and base plate. To mount the load cell and the spacing washers to the load plate and the base plate, two countersunk head screws were used. The weighing platform was standing on three equidistant adjustable support feet (Fig. $1 \mathrm{~h}$, M6x1 machine screws, h15.5 cm) integrated in the base plate. This allowed to level the weighing platform, which is important for accurate load cell measurements. A counter nut above the base plate fixed the position of the weighing platform. 


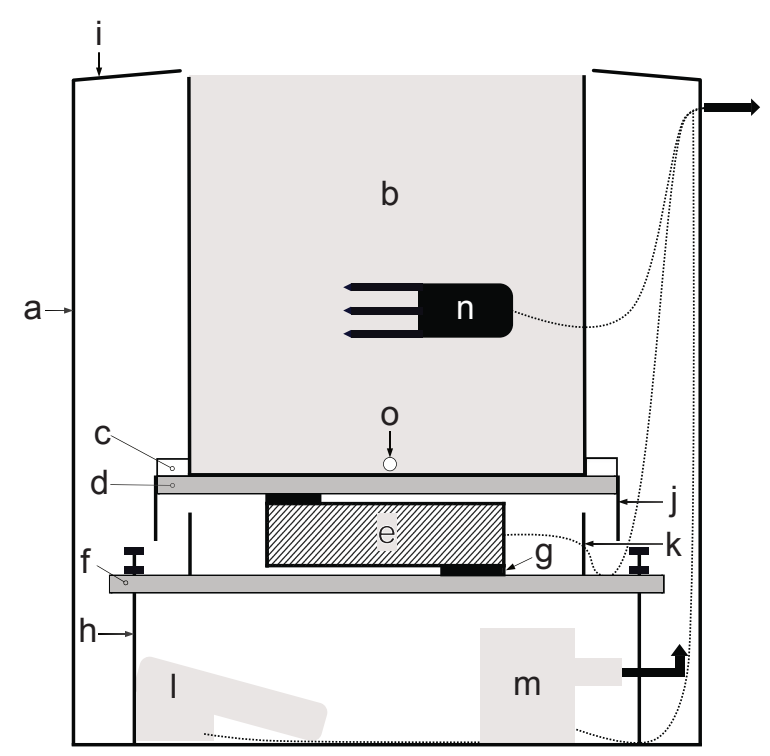

Fig. 1. Schematic ML design: a) outer part, b) ML pot, c) socket, d) load plate, e) load cell, f) base plate, g) spacing washer, h) support feet, i) cover lid, $\mathbf{j}$ ) water guide, $k$ ) water and dirt protection, l) float switch, $m$ ) bilge pump, $n$ ) soil moisture and temperature sensor, o) drainage-water outlet.

\subsubsection{Drainage water flow}

To avoid stagnating water inside of ML pots, a passive drainage water flow path was made. The drainage-water was guided away from the load cell to a reservoir to protect the load cell from suspended matter. Suspended matter can be carried along with drainage water and could impede the function of the load cell by blocking the load cell bending. Drainage water beyond soil field capacity was allowed to flow out from the bottom of the ML pot via drainage-water outlets. Three drainage-water outlets (Fig. $1 \mathrm{o} ; \mathrm{d} 0.8 \mathrm{~cm}$ ) were drilled equidistantly into the lateral side of the ML pot as close as possible to the bottom. The drainage-water outlets were protected with a metal mesh to prevent erosion of ML soil during heavy rainfall events. Excessive water could follow a passive drainage path from the top of the load plate, guided by a water guide (Fig. $1 \mathrm{j} ; \mathrm{h} 3 \mathrm{~cm}, \mathrm{t} 0.4 \mathrm{~cm}$ ), to the base plate. From the base plate

190 water could flow to an approximately $10 \mathrm{~cm}$ high reservoir below the base plate. If the collected water in the reservoir exceeded a certain threshold, a float switch (Fig. 11; Fujian Baida Pump, Fuan, China) gave a signal to a bilge pump (Fig. 1m; Fujian Baida Pump, Fuan, China) that pumped the water away from the ML system (schematically shown with an arrow in Fig. 1) via a flexible tube (d2 cm). The load cell was protected from drainage water flow by a rectangular water and dirt protection (Fig. 1k, PVC

$195 \mathrm{XT}, 25 \mathrm{~cm} \times 10.5 \mathrm{~cm}, \mathrm{~h} 4 \mathrm{~cm}$ ). It was glued at the base plate around the load cell and made watertight with silicon.

Rainfall could enter also in the gap between the ML pot and the outer part of the ML system. To minimize this water collection, a cover lid (Fig. i) made of a PVC-XT ring (outer d47 cm, inner d26 cm) was constructed. The cover lid had an inclination of $7^{\circ}$ towards the outside. This was done by putting 
200 the cover lid in a heated oven at $90{ }^{\circ} \mathrm{C}$ and then pressing it towards a custom-made wooden fit with the desired form, till it had cooled down. The slanted cover lid resulted in a preferred water flow towards the surrounding and thereby prevented water flow towards the inside of the ML system. Furthermore, it protected the ML pot from incident solar radiation, also minimizing potential heating effects. Wiring of the load cell, the float switch, the bilge pump as well as the soil temperature and moisture sensors (see

205 Section 2.2.8) were bundled and led out close to the top of the outer part of the ML system (schematically shown with an arrow in Fig. 1).

In the design as used here, i.e. to quantify NRW inputs during dry spells and drought periods in summer, drainage water was allowed to freely drain from the ML pots. We assumed that no drainage occurs during dry spells and drought periods, when NRW inputs potentially are important as an

210 additional water source to plants. However, to use the ML system more universally, it is recommended to add an additional sensor to quantify drainage water flow (see Supplementary Material).

\subsubsection{Soil monolith preparation}

To retrieve an undisturbed soil monolith with intact grass vegetation, we used an empty ML pot that was placed upside down at the place of interest from where the monolith was to be retrieved. First, we trenched the soil with a long spade around the ML pot. Then we removed the soil around the ML pot with small shovels, which allowed pressing the ML pot into the soil. We continued until the top of the ML pot was at ground level. Finally, the contact with the soil could be cut at the bottom with a spade. The reversed soil monolith was transferred to a second ML pot to be upright again and was ready for installation on the weighing platform.

\subsubsection{Data collection, storage and delivery}

Data from all sensors were collected by an Arduino-type MEGA 2560 PRO microcontroller (RobotDyn, Zhuhai, China), which was installed on a custom-made printed circuit board (PCB). The voltage signal coming from the load cells was digitised by a 24-bit analog-to-digital converter for weigh scales (LM711, SparkFun Electronics, Niwot, USA). For each load cell, a separate analog-to-digital converter 225 was used. After collecting and processing the data of the load cells and the other sensors, the data were stored as one-minute averages on a micro-SD card (MicroSD 16 Gb, Kingston Technology Company Inc., Fountain Valley, USA) inserted in the slot of a micro-SD breakout board (MicroSD card breakout board 254, Adafruit Industries, New York, USA). Then, the data were transferred to our data server every five minutes by using Internet of Things (IoT) technology. To send the data, a breakout board

230 (RFM9X LoRa Radio, Adafruit Industries, New York, USA) connected to the open TheThingsNetwork was used. TheThingsNetwork uses a Long Range Wide Area Network (LoRaWAN) protocol. A realtime clock (DS3231 for PI, HiLetgo, Shenzhen, China) was installed on the PCB to obtain exact timestamps.

\subsubsection{Load cell data low-pass filtering}

235 Load cell data are prone to noise. To cancel the noise related to temperature fluctuations, the load cells used four strain gauges in a Wheatstone bridge configuration. Thus, noise visible in the data mostly 
originated from electrical noise, fluctuations in wind speed and atmospheric pressure. To minimize this noise, we used a data filtering algorithm on the microcontroller. The microcontroller measured the load cells nominally at $3.3 \mathrm{~Hz}$ in combination with the retrieval of measurements from other sensors. The raw load cell data were then stored in an averaging window (ring memory), where the oldest values were replaced by the newest ones. The upper and lower $15 \%$ of these values within the averaging window were discarded, and the remaining values were averaged. From the low-pass filtered signal, one-minute means were stored on the micro-SD card. For data delivery via IoT, these mean values were further averaged over five-minute intervals to comply with the allowed IoT bandwidth for data transfers.

\subsubsection{Load cell calibration and determination of accuracy}

Calibration runs for ML and the determination of the accuracy of the measurements were performed in a laboratory with closed windows and doors to avoid any influence of air turbulence on load cell readings. Raw data were filtered as described in Section 2.2.5 during load cell calibration of the ML. A

250 two-point calibration was performed on every single ML using calibration mass. For mass increases up to $500 \mathrm{~g}$, calibration mass complying with the OIML F1 standard were used (Mettler Toledo, Greifensee, Switzerland). The maximum permissible error of these calibration mass is $\pm 2.5 \mathrm{mg}$. For mass increases of $1000 \mathrm{~g}$, custom made mass of steel were used. Their mass was determined on a laboratory scale (XS4002S DeltaRange, Mettler Toledo, Switzerland) which was calibrated and certified for determining mass up to $4.1 \mathrm{~kg}$ with an accuracy of $\pm 0.01 \mathrm{~g}$. First, a zero-point calibration was carried out, then the span was set to $15045.2 \mathrm{~g}$, as this was the mass which most moist ML pots had. The offset from the zero-point calibration was used together with the span calibration value in the code running on the microcontroller. The absolute accuracy of the load cells was tested on $2^{\text {nd }}$ April 2019 , by loading calibration mass on the weighing platform, in the range of $0 \mathrm{~kg}$ to $19.5 \mathrm{~kg}$. The mass

260 was increased stepwise by $500 \mathrm{~g}$. The maximum mass was set to $19.5 \mathrm{~kg}$ to avoid an overload damage of the load cell. Three repetitions were performed. We visually aggregated the values delivered by the microcontroller with one digit, because values after the second digit were fluctuating. A linear regression was performed in order to assess the relationship between target mass and load cell mass. Moreover, a relative calibration was performed on $7^{\text {th }}$ April 2019. We investigated the accuracy of a

265 load cell with relative mass changes. A base mass, ranging from $10 \mathrm{~kg}$ to $19.5 \mathrm{~kg}$, was loaded on the weighing platform, then a $100 \mathrm{~g}$ calibration mass was added to the base mass. Accuracy of relative mass changes was determined with three replications. To test accuracy also under field conditions, we regularly performed a loading/unloading experiment after Nolz et al. (2013), by loading 5 to $10 \mathrm{~g}$ calibration mass on the ML and noting the mass before and after the loading.

\section{2.2.7 Evaluation of the effects of ML size on plant growth, canopy temperatures, and soil moistures and temperatures}

Plant growth of the ML system was evaluated by comparing individual plant heights in the ML pots versus the control (surrounding). Plant heights were measured from ground level to maximum standing height. Plant heights of Trifolium pratense, Plantago major and Rhinanthus alectorolophus were 
measured at CH-FRU on 26 July 2019, with three replications per species and treatment (ML pot, control). To test for a statistically significant difference between plant heights of ML pots and the control (surrounding) we used a $t$-test $(\mathrm{n}=3)$. To compare canopy temperatures of ML and the control (surrounding) during a NRW input period, we used a thermal camera (testo 882, Testo AG, Lenzkirch, Germany), with a thermal sensitivity of $<60 \mathrm{mK}$. Thermal infrared images were taken from 18:27 to 05:15 (UTC) of ML vegetation and of the control (surrounding) at CH-FRU during a dew night on 24 to 25 June 2019. Thermal images of the control (surrounding) were taken in a distance of ca. $100 \mathrm{~cm}$ from the ML system, to exclude any potential influences of the ML system on its immediate surrounding. To compare thermal images of the ML surface with the control, we considered standard deviation to account for spatial variability. Soil moisture and temperature data of ML pots and the control

285 (surrounding) were retrieved by soil temperature and moisture sensors (Fig. 1n; 5TM, Meter Group AG, Munich, Germany), installed at a soil depth of $15 \mathrm{~cm}$. As a control, one additional sensor was placed outside the ML system at the same depth in the surrounding. We measured over a period from beginning of May till mid of October 2019. Soil moisture data were compared as water filled pore space (WFPS). WFPS was used to make soil moisture values better comparable, by minimizing the effects of spatial soil texture, e.g. different gravel content, that might have occurred in close proximity of the sensors. Higher or lower gravel content could bias soil saturation point values. WFPS values were calculated relative to a saturation point $(100 \%)$, which was reached, when the soil was heavily saturated with water. To test if the numerical difference of WFPS values of ML pots and the control (surrounding) stayed constant over time, we used a cointegration test after Engle and Granger (1987), which can be used to test for co-movement of two non-stationary variables. To test if the WFPS time series were non-stationary, we used an Augmented Dickey-Fuller (ADF) test. To perform all statistical tests, we used the programming language Python and the package statsmodels (Skipper et al., 2010).

\subsubsection{Calculation of NRW amounts and differentiation of NRW inputs}

We differentiated six types of NRW events with ML and ancillary sensors, i.e., (1) dew only, (2) hoar

300 frost only, (3) fog only, (4) rime only, (5) combined dew and fog events, and (6) combined hoar frost and rime events. During all six event types, a mass increase was expected on the ML. The NRW amounts (NRW amount) were calculated using equation (1):

$$
N R W_{\text {mass }}= \begin{cases}M L_{\max 1 m}-M L_{\min 1 m}, & \text { precip }=0 \\ 0, & \text { precip }>0\end{cases}
$$

where $\mathrm{ML}_{\max 1 \mathrm{~m}}$ is the maximum value of the one-minute mean $\mathrm{ML}$ mass (all three ML values averaged every minute) over a time period of 24 hours (from 12:00 to 12:00 UTC), $\mathrm{ML}_{\min 1 \mathrm{~m}}$ is the minimum value of the one-minute mean ML mass over the same time period. The resulting $\mathrm{NRW}_{\text {mass }}$ (in grams) was then transformed to $\mathrm{mm}$. If rainfall occurred during an analyzed 24-hour period, that period was excluded, and thus NRW input was undefined (zero), except the rain event occurred directly after the NRW input event. Rain events were determined by the rain gauge measurements at the site. Time periods with a snow cover as determined visually from digital images were not considered in the analysis. To distinguish between different types of NRW inputs, we used the information from all 
ancillary sensors. Often dew and fog or hoar frost and rime occurred in combination, e.g. after sunset, dew formation occurred, when the atmosphere cooled further down till the atmosphere got highly saturated, fog started to form. We termed such events combined dew and fog events, or hoar frost and rime events, respectively. The leaf wetness sensor was used to sense condensation (during dew only and hoar frost only events), NRW droplet interception and impaction (during fog, rime, combined dew and fog, combined hoar frost and rime events), and to sense an absence of condensation (during events when less condensation is expected to occur, e.g. water vapor adsorption or dew formation on soil). The visibility sensor was used to distinguish between events with reduced visibility below $1000 \mathrm{~m}$ (fog, rime events), and events without reduced visibility (dew only, hoar frost only events). To distinguish between fog and rime events from dew and hoar frost events, the temperature sensor of the nearby agrometeorological station was used. When temperature dropped below $0{ }^{\circ} \mathrm{C}, \mathrm{NRW}$ inputs were attributed to rime and hoar frost.

\section{Results}

\subsection{Accuracy}

Three replications showed a perfect linear correlation $\left(\mathrm{R}^{2}=1\right)$ between target mass and load cell mass. Target mass was retrieved from the microcontroller after data filtering (see Section 2.2.5). Data with a resolution of $0.1 \mathrm{~g}$ were used. The root mean square errors (RMSE) for comparisons of target mass to load cell mass of three replications were $0.43,0.47$ and 0.36 , respectively. The standard error (SE) of the parameter estimates of three replications were $\pm 0.13, \pm 0.14$ and \pm 0.11 , respectively.

(a)

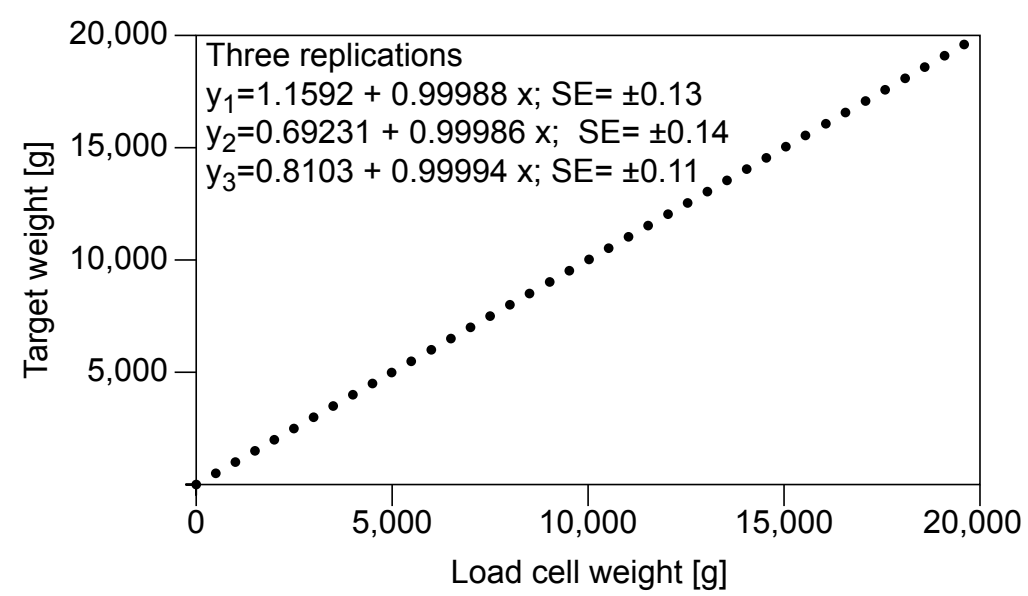

(b)

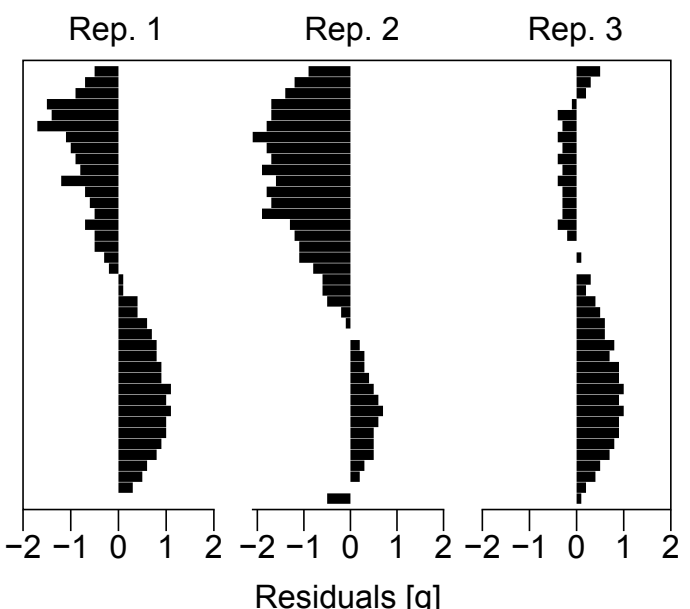

Fig. 2 (a) Absolute calibration of a load cell placed in a weighing platform. Three replications (overlapping data points) are shown with SE of the intercept. (b) The residuals from the target mass of three replications (Rep. 1 to 3 ) were in the range of $\pm 2 \mathrm{~g}$.

NRW inputs occur during events with a finite time period, thus for NRW input studies, the relative change in mass from start to end of that time period is of interest. A $100 \mathrm{~g}$ change with the given ML 
size translated to a change of $2 \mathrm{~mm}$ water input. The residuals were in the range of $\pm 0.25 \mathrm{~g}$ or \pm 0.005 mm equivalent water input, which represents the accuracy of the ML system.

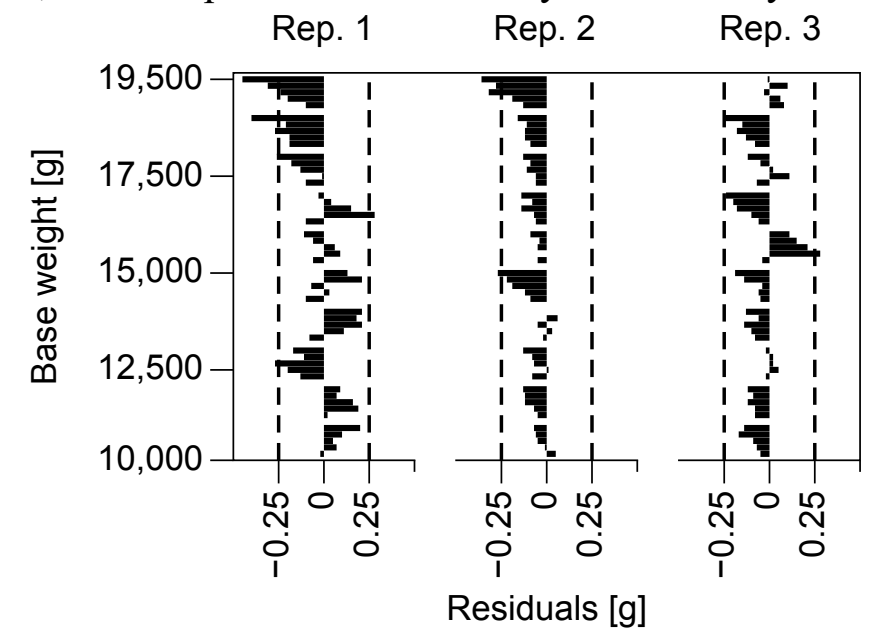

Fig. 3 Residuals of three replications (Rep. 1 to 3) with relative mass changes of $100 \mathrm{~g}$.

A zero-point offset calibration combined with data filtering (see Section 2.2.5) gave us not only a more accurate zero-point value, but also a more accurate span value. An accurate span value reduced fluctuating values from load cell readings and gave us stable measurements when mass changed over time. The precision was determined with three replications and was $\pm 0.28 \mathrm{~g}$, equivalent to $\pm 0.005 \mathrm{~mm}$ water input. With a base mass over $18.5 \mathrm{~kg}$, the precision was slightly lower, with $\pm 0.45 \mathrm{~g}$ equivalent to $\pm 0.009 \mathrm{~mm}$ water input. The digital resolution of the ML system was $0.01 \mathrm{~g}$, which corresponds to $0.0002 \mathrm{~mm}$ equivalent water input, and is thus two orders of magnitude better than the physical resolution provided by our ML system. Regular loading/unloading experiments after Nolz et al. (2013) showed deviations in the range between $\pm<0.1 \mathrm{~g}( \pm<0.002 \mathrm{~mm})$ and $\pm 0.4 \mathrm{~g}( \pm 0.008 \mathrm{~mm})$ and confirmed thereby high accuracy also under field conditions. Thus, the data acquisition of the ML system was accurate enough to provide high accuracy.

\section{3.2 Differentiation among different types of NRW inputs}

Our ML system allowed differentiating among different types of NRW events when the ML measurements were combined with ancillary sensors. During a combined dew and fog event (Fig. 4a), we measured an increase in mass on the ML, an increase in leaf wetness (uncalibrated sensor voltage), while visibility was partially below $1000 \mathrm{~m}$ (intermittent fog event). During a dew only event, we measured an increase in mass on the ML, beside increased leaf wetness values, while visibility stayed above $1000 \mathrm{~m}$ throughout the event (Fig. $4 \mathrm{~b}$ ). During a potential water vapor adsorption event, there was only an increase in mass on the ML, whereas no condensation occurred on the leaf wetness sensor while the visibility stayed well above $1000 \mathrm{~m}$ (Fig. 4c). Potential effects of wind speed fluctuations that exert a force on the ML and could thereby be confounded with water vapor adsorption, could be excluded by nearby wind measurements. Wind speed during the water vapor adsorption period 
remained below $1 \mathrm{~m} \mathrm{~s}^{-1}$. Mass increases on the ML could be attributed to hoar frost if air temperature was below $0{ }^{\circ} \mathrm{C}$ or to rime during events with reduced horizontal visibility $<1,000 \mathrm{~m}$ and temperatures below $0{ }^{\circ} \mathrm{C}$. The highest water gain of the NRW input events shown in Fig. 4 was $0.4 \mathrm{~mm}$ and originates from the combined dew and fog event; the water input from the dew only event was $0.2 \mathrm{~mm}$, and the lowest water input with $0.06 \mathrm{~mm}$ came from the potential water vapor adsorption event.

(a)

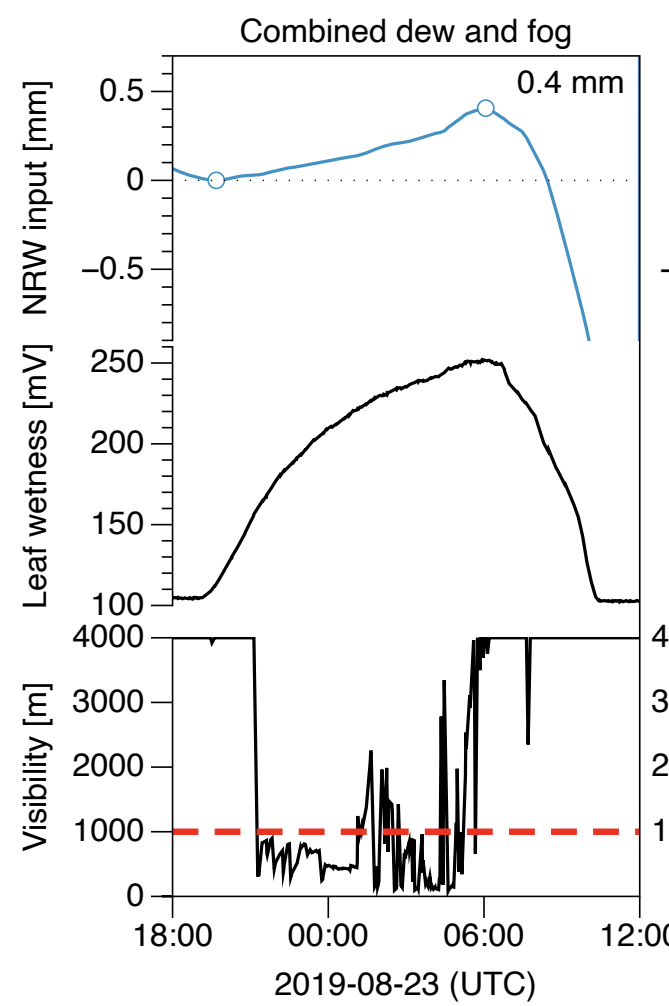

(b)

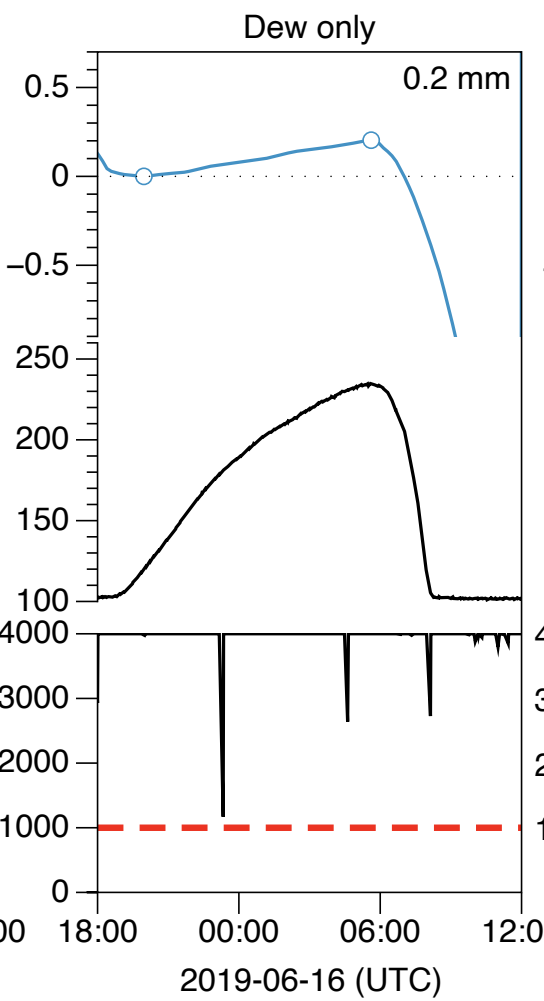

(c)

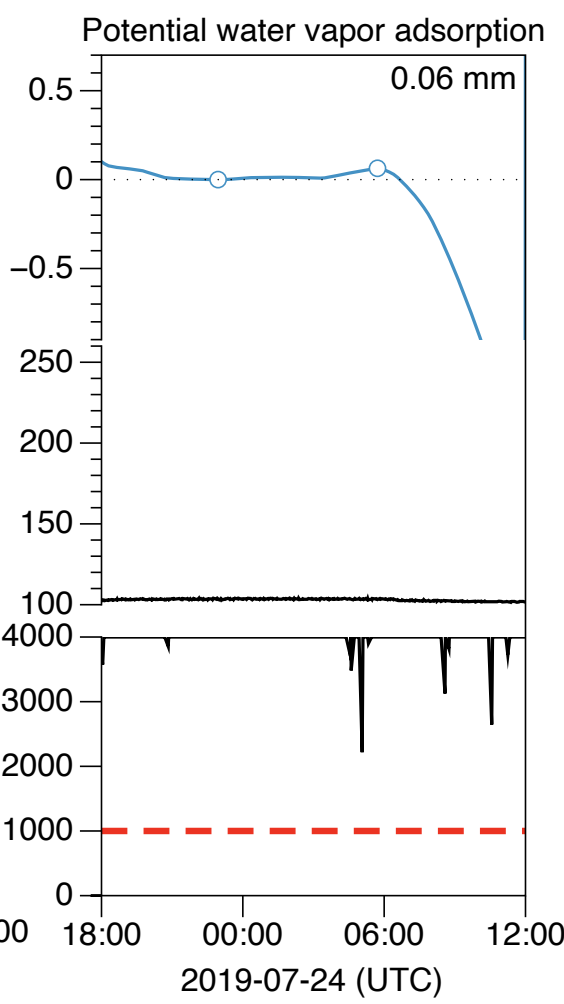

Fig. 4. Differentiation of different NRW input events with the ML system and ancillary sensors: (a) Combined dew and fog event; (b) Dew only event; (c) Potential water vapor adsorption event. The black dashed line indicates the zero line. The red dashed line is the threshold for fog events with a visibility $<1000 \mathrm{~m}$. Visibilities $>4000 \mathrm{~m}$ were reported as $4000 \mathrm{~m}$. Blue circles indicate start and end of NRW input events. 
Table 1. Cross table to indicate different criteria for differentiation of NRW events. All NRW events lead to increase of ML mass, ancillary sensors of leaf wetness, visibility and temperature are needed to differentiate between NRW events.

\begin{tabular}{|c|c|c|c|c|}
\hline $\begin{array}{l}\text { NRW event } \\
\text { type }\end{array}$ & $\begin{array}{l}\text { ML mass } \\
\text { increase }\end{array}$ & Leaf wetness & $\begin{array}{l}\text { Visibility < } \\
1000 \mathrm{~m}\end{array}$ & $\begin{array}{l}\text { Temperature }< \\
0^{\circ} \mathrm{C}\end{array}$ \\
\hline Dew & + & + & - & - \\
\hline Hoar frost & + & + & - & + \\
\hline Fog & + & + & + & - \\
\hline Rime & + & + & + & + \\
\hline $\begin{array}{l}\text { Combined dew } \\
\text { and fog }\end{array}$ & + & + & + & - \\
\hline $\begin{array}{l}\text { Combined hoar } \\
\text { frost and rime }\end{array}$ & + & + & + & + \\
\hline $\begin{array}{l}\text { Potential water } \\
\text { vapor } \\
\text { adsorption }\end{array}$ & + & - & - & - \\
\hline
\end{tabular}

\subsection{Influence of ML system design on plant canopy temperature}

Canopy temperature did not differ between ML vegetation and control (Fig. 5a, 5b). The standard deviation of temperature data between ML surface and the control was throughout the observation period $<0.5^{\circ} \mathrm{C}$. Soil temperature in the ML pot 1 was higher than in the control plot at the beginning of the dew formation period (Fig. 5c), but equaled control soil temperatures towards the end. Dew

395 formation started at 18:53 and ended at 06:07 UTC (Fig. 5d). Dew water input was 0.24 mm, showcased for ML 1, even though dew formation occurred during that night on all three ML installed at the site. 

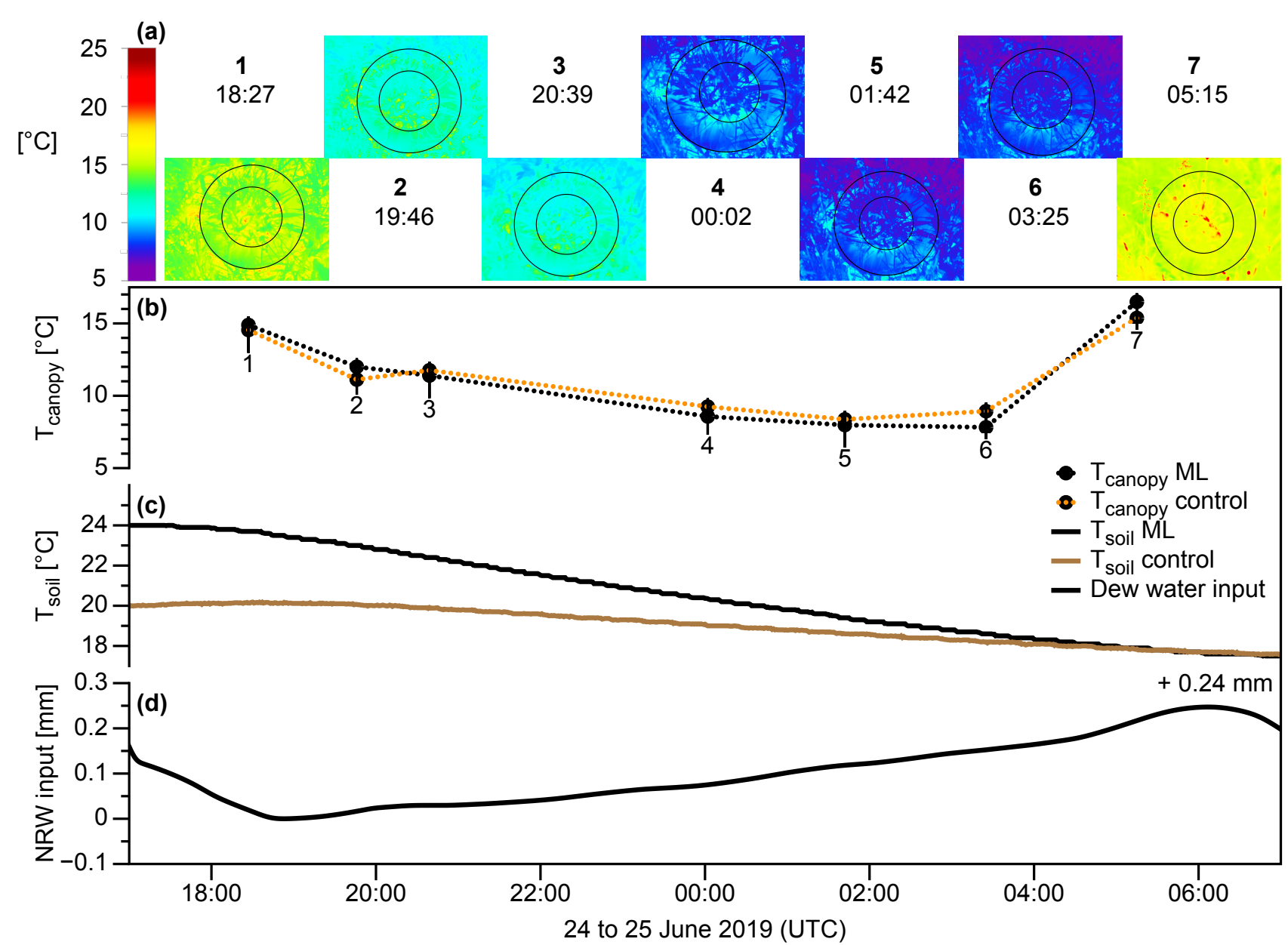

Fig. 5. Canopy temperatures (a, b), soil temperatures (c), and NRW input (d) of ML1 and the control (surrounding area) at CHFRU during 24 to 25 June 2019. Time of day (HH:MM) is given in UTC time. The thermal infrared images (a) show the ML pot (small circle) with the cover lid (between small circle and big circle) and the surrounding (outside of big circle) during selected time points (1-7) of a dew night. Image size is ca. $75 \times 75 \mathrm{~cm}$. To compare ML pot temperatures to temperatures of the surrounding, separate images were taken in a distance of ca. $100 \mathrm{~cm}$ (images not shown here) with a size of ca. $75 \times 75 \mathrm{~cm}$, to exclude any potential influence of the ML on its approximate surrounding.

\subsection{Influence of ML system design on plant growth}

Plant heights of Trifolium pratense, Plantago major and Rhinanthus alectorolophus did not differ between ML pots and the control (t-test, $p>0.05, n=3$ ), also variability did not differ (F-test, $p>0.05$, $\mathrm{n}=3$ ). Additional measurements of mean and maximum vegetation height on 14 August 2019 showed also no statistically significant difference ( $t$-test, $p>0.05, \mathrm{n}=3$; data not shown). 


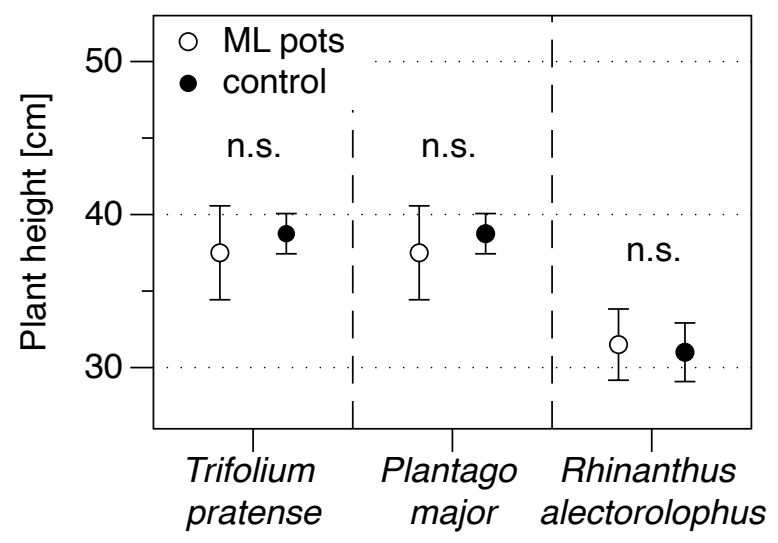

Fig. 6. Comparison of plant height of three plant species at CH-FRU (measured on 26 May 2019) growing in ML pots versus the same species growing in the open field (control). Error bars are showing standard errors $(n=3)$, n.s. stands for no statistically significant difference.

\subsection{Influence of ML system design on soil moistures and temperatures}

WFPS data of ML pots 1 , and ML pot 2 were very similar, and closely matched the control (Fig. 7a). WFPS values of ML pot 3 showed a higher dynamic, but closely followed the temporal pattern of the control and ML pots 1 and 2. The numerical distance between WFPS of ML pots and the control was constant over time (Engle-Granger two step cointegration test; $p<0.05$ ). This indicates that soil moisture data of ML pots and the control were in general not different. However, during a prolonged no-rainfall period in summer (Fig. 7a, marked with red box), WFPS of ML pots decreased faster in comparison to the control. Since lower soil moisture values can result in a lower heat capacity of the soil, we assessed whether lower WFPS values inside ML pots may have an influence on soil temperature during non-rainfall periods (Fig. 7b).

WFPS of ML pot 1 and the control (WFPS in the surrounding) (Fig. 7b) showed the same increasing trend, while deviation of WFPS of ML pots from the control (Fig. 7a, marked in red) increased with time (same pattern as of ML pot 1 was also evident on ML pot 2 and ML pot 3, data not shown). From this we conclude that soil temperatures inside ML pots during the most relevant hours of day when dew forms (during the night before sunrise) were not strongly influenced by a lower water content and its resulting lower heat capacity. Nocturnal temperature minima almost perfectly agreed between ML pot 1 and the control, while the daily temperature range of ML pot 1 was double compared to the control (Fig. 7b). Over the period from May till October 2019 (Fig. 7c), the hourly mean soil temperature deviations of ML pot 1 from the control at ranged between $-0.14{ }^{\circ} \mathrm{C}$ around sunrise and $2.57{ }^{\circ} \mathrm{C}$ in the later

435 afternoon. Thus, during most of the night when NRW input occurs, the temperature differences between the soil of ML pots and the control are typically less than $1{ }^{\circ} \mathrm{C}$. 
a)

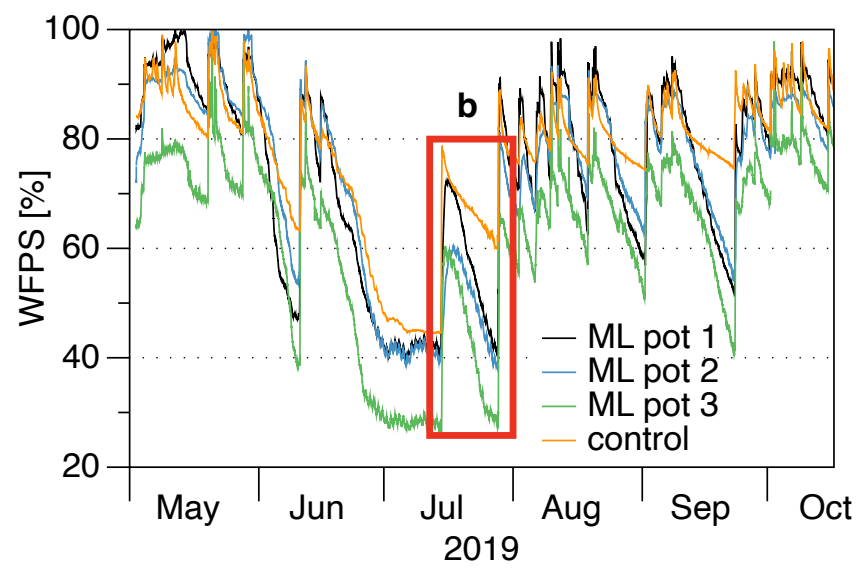

b)

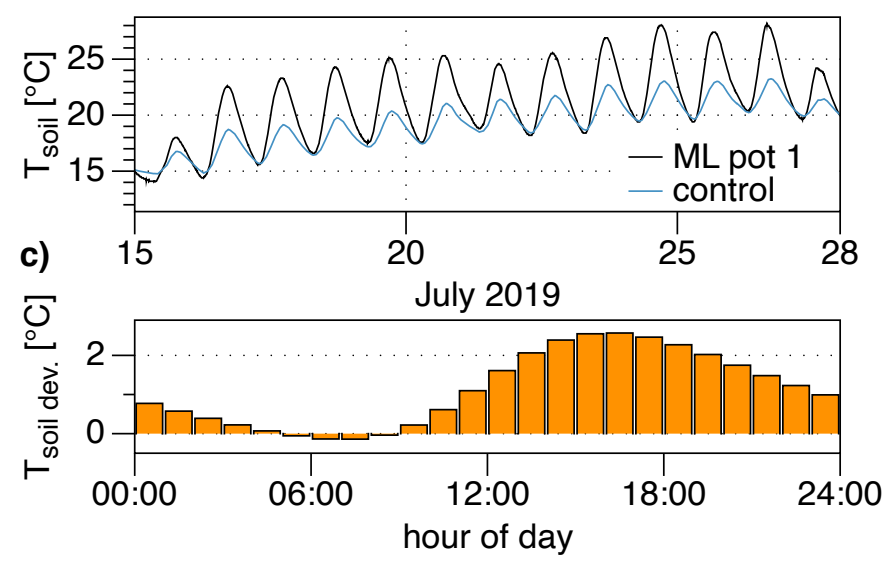

Fig. 7. (a) Comparison of WFPS (based on soil moisture measured at $15 \mathrm{~cm}$ depth) inside the ML pots versus the control from beginning of May till mid of October 2019 at CH-FRU; ( b) Soil temperature from ML pot 1 at CH-FRU during a non-rainfall period in July (marked with red box in panel a); (c) Soil temperature deviations of ML pot 1 from the control by hour of day during the same period as marked in panel a and used in panel $b$.

\subsection{NRW inputs over one year}

There were a total of 127 NRW input events at CH-FRU over one year (May 2019 to end of April 2020;

445 Fig. 8). The most frequent event was dew formation with 85 events, followed by hoar frost formation with 21 events, and combined dew and fog events with 13 events. Less frequent were fog only events (5 in total), combined hoar frost and rime events ( 2 events), and rime events only ( 1 event). $11 \mathrm{NRW}$ events were observed when leaf wetness values stayed low, potentially indicating water vapor adsorption events or dew formation on soil. Potential water vapor adsorption events occurred during two time periods: period 1 in July 2019, period 2 in April 2020. During period 1, a single potential water vapor adsorption event occurred, whereas during period 2 ten such events occurred. During both periods rainfall was low, ten days before the event in period 1 the cumulative rainfall was only $9.6 \mathrm{~mm}$, in period 2 the cumulative rainfall between $14 \mathrm{March}$, the last bigger rainfall with $12.3 \mathrm{~mm}$, and 23 April was only $13.7 \mathrm{~mm}$. The soil moisture during both potential water vapor adsorption periods was rather low, with WFPS values of ca. $45 \%$. This indicates a potential water vapor gradient from the atmosphere to the soil, favorable for water vapor adsorption. The cumulative NRW input over 12 months was $15.92 \mathrm{~mm}$, compared to $1580 \mathrm{~mm}$ annual precipitation, during the third warmest year in Switzerland since weather recordings started in 1864 (MeteoSchweiz, 2020). Dew events contributed ca. $64 \%$, combined dew and fog events ca. $16 \%$, hoar frost events ca. $12 \%$, fog events ca. $5 \%$, hoar frost and rime combined ca. $0.9 \%$ and a rime event ca. $0.2 \%$ to the total NRW input over 12 months. 


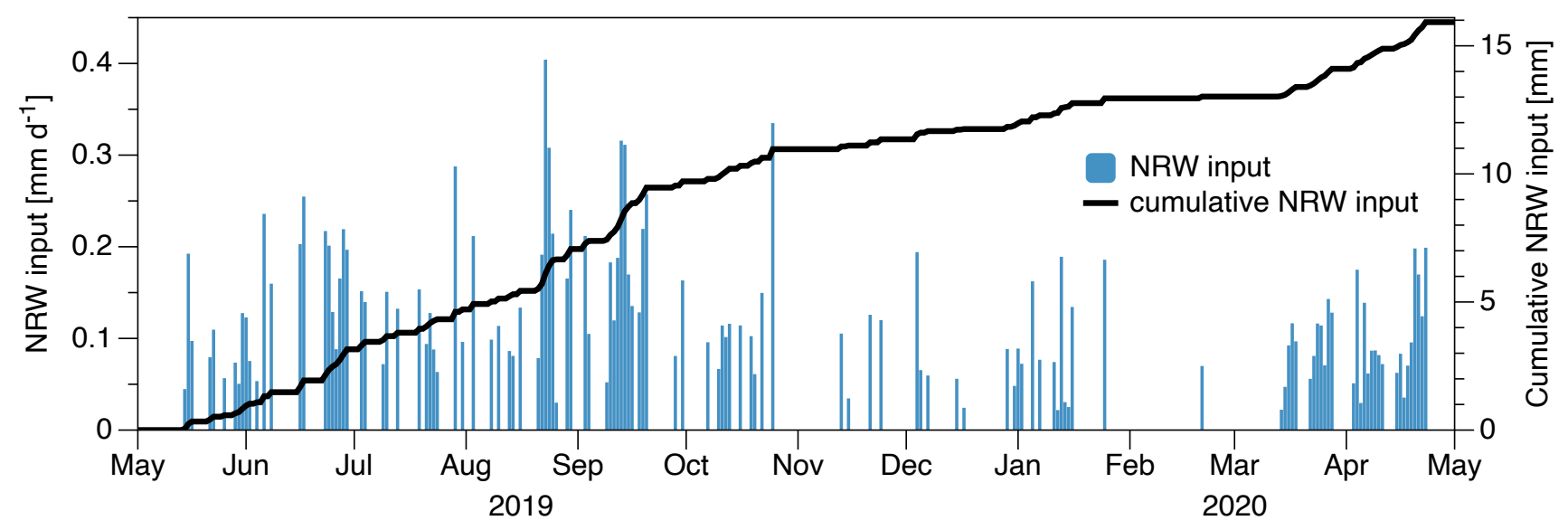

Fig. 8. Daily NRW inputs at CH-FRU over one year, starting on 2nd May 2019 till 2nd May 2020. The blue bars indicate NRW events with their corresponding NRW input per day. The black line indicates the cumulative NRW input over one year. The annual total NRW input was $15.9 \mathrm{~mm}$, about $1 \%$ of total precipitation during this time.

The mean NRW input over all events was $0.12 \mathrm{~mm}$, with the highest single input of $0.4 \mathrm{~mm}$ by a fog event, and the lowest input of $0.021 \mathrm{~mm}$ by a hoar frost event. On a monthly basis, the months with highest NRW inputs were September with $2.64 \mathrm{~mm}$, August with $2.35 \mathrm{~mm}$, and June with $2.32 \mathrm{~mm}$. The cumulative NRW input from May until September was $9.7 \mathrm{~mm}$. Thus, NRW inputs were about $1 \%$ of the total water input during this very hot summer 2019. But also, at the monthly scale, NRW inputs can be remarkable: in April 2020, the month with the smallest rainfall $(51.8 \mathrm{~mm})$, the fraction of NRW input was 3.5\%. The average monthly NRW input was highest in September with $0.088 \mathrm{~mm}$, when the nights were longer than in summer months, and thus the probability for NRW inputs was increasing with the duration of the night. However, observed average monthly NRW inputs ranked second and third in terms of amount in June and August when nights were much shorter than in September. The relationship between NRW input as a function of actual NRW input duration (Fig. 9) was not very strong, but when durations were binned into 10 bins of equal widths, a clear trend of increasing NRW inputs with increasing NRW input duration emerged (Fig. $9, \mathrm{R}^{2}=0.9, \mathrm{p}<0.0001$ ). The average NRW inputs increased by $8.8 \pm 0.9 \mu \mathrm{m}$ per 60 minutes of NRW input duration (slope: $0.14 \pm 0.015 \mu \mathrm{m}$ ). The actual average monthly NRW input durations were not directly linked to the potential NRW input durations (i.e., the time between sunset and sunrise), as there was no statistically significant linear relationship between actual average monthly NRW inputs and potential average monthly NRW input duration $\left(\mathrm{R}^{2}=0.16, \mathrm{p}>0.1\right.$; data now shown $)$. 


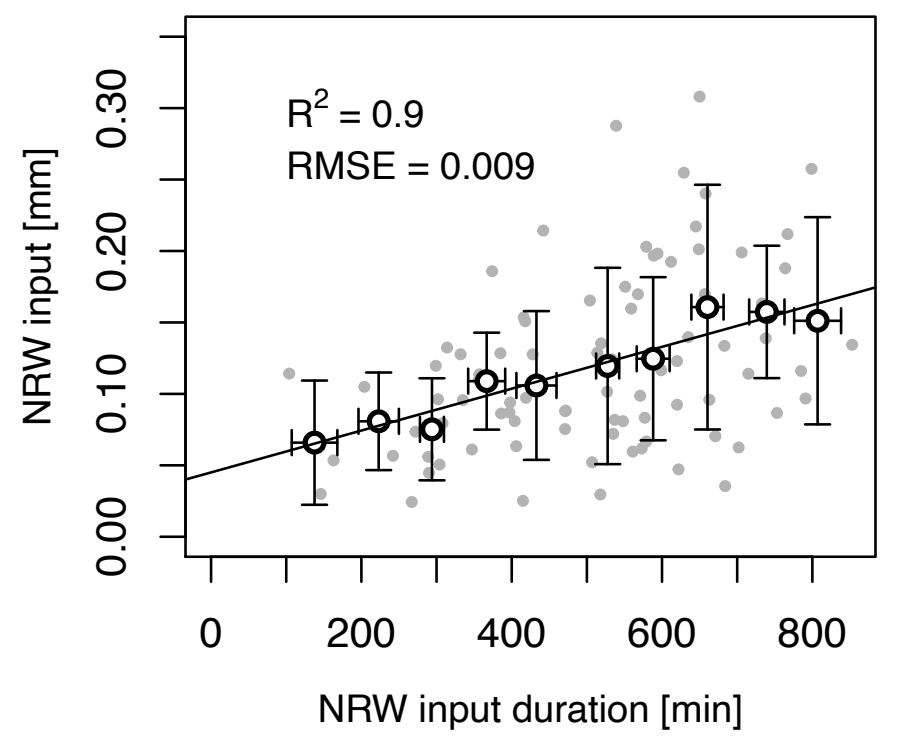

485 Fig. 9. The relationship of actual NRW input as a function of actual NRW input duration from 12 months of NRW inputs. NRW inputs were binned to 10 bins of equal width covering the entire data range of the NRW input duration. Horizontal and vertical whiskers indicate the SD of the available data within each bin relative to the respective bin average (open circles). There is a strong linear relationship $(R 2=0.9, p<0.0001)$ between actual $N R W$ input and actual NRW input duration.

\section{Discussion}

\subsection{Accuracy of the ML system}

The high accuracy of our newly developed ML system allowed capturing even very small NRW events such as the potential water vapor adsorption event with $0.06 \mathrm{~mm}$ shown in Fig. 4c. It was possible to capture NRW events with an accuracy of $\pm 0.25 \mathrm{~g}$ with pots that weigh roughly $15 \mathrm{~kg}$ in total. This corresponds to an accuracy of $\pm 0.005 \mathrm{~mm}$ of water inputs. The accuracy would be even higher with a relative mass change less than $100 \mathrm{~g}$ (equivalent to $2 \mathrm{~mm}$ water input), which is true for most NRW events. The accuracy of our ML system was four orders of magnitude better than reported for many other studies (see Table 2). Feigenwinter et al. (2020) could achieve on average (depending on calibration date) the same accuracy, although with a lower depth of the ML pot $(6.5 \mathrm{~cm})$ and a lower 500 weighing capacity $(7 \mathrm{~kg})$. The high accuracy of our ML system was achieved by a combination of factors, such as using a state-of-the-art load cell in combination with continuous high frequency data filtering as well as ancillary data. For example, wind measurements were crucial to exclude possible 
effects of wind. Wind could act as a force on ML and increase thereby mass, although nocturnal wind speeds are in general much lower than during daytime (Groh et al., 2018). With high frequency data filtering, we obtained one stable decimal place, which enabled exact calibration. Factory calibration is the same for all load cells of the same model, but when an individual calibration is made, the differences among individual load cells are substantial, and hence highest accuracy always requires a load-cell specific calibration by the user. Construction details that promoted accuracy were the frictionless gap construction between ML pot and cover lid, as well as the three adjustable support feet

510 on which the weighing platform was centered on the load cell. This is needed because after burial, a ML system may accidentally tip, twist and be thrown out of balance (Uclés et al., 2013). The low-cost microcontroller had enough computing power to continuously process data from multiple sensors, while consuming little energy. Thus, our ML system could also be powered by solar panels.

Precision of our ML system was $\pm 0.005 \mathrm{~mm}$ equivalent water input. With a base mass over $18.5 \mathrm{~kg}$, the precision was lower, with $\pm 0.009 \mathrm{~mm}$ equivalent water input. However, in the field, ML pots were weighing less than $18.5 \mathrm{~kg}$, even when soil was moist. This precision was unprecedented, only topped by manual ML weighing on an electronic balance (Jia et al., 2014). Manual weighing is, however, very labor intensive and consequently unsuitable for long-term NRW studies.

The digital resolution of our ML system was $0.0002 \mathrm{~mm}$. This resolution was in the range reported by

520 Uclés et al. (2013). Comparison of accuracies, precisions and resolutions with other studies is often hampered, because the distinct terms accuracy, precision and resolution are often misconceived. The load cell capacity of $20 \mathrm{~kg}$ in our ML system is relatively large compared to other ML studies. NRW input studies with ML had a load cell capacity in the range from $0.3 \mathrm{~kg}$ (Brown et al., 2008), $1.5 \mathrm{~kg}$ (Kaseke et al., 2012), $3 \mathrm{~kg}$ (Uclés et al., 2013), $6 \mathrm{~kg}$ (Maphangwa et al., 2012; Matimati et al., 2013), up to $7 \mathrm{~kg}$ (Feigenwinter et al., 2020). 
545 Table 2. Comparison of accuracies, precisions and resolutions of ML and LM for NRW studies.

\begin{tabular}{lll}
\hline Accuracy of ML and LM & Additional information & Reference \\
\hline $\pm 0.005 \mathrm{~mm}$ (mean) & $\begin{array}{l}\text { Accuracy ranged from } \pm \\
0.001 \mathrm{~mm} \text { to } \pm 0.02 \mathrm{~mm} \\
\text { depending on calibration } \\
\text { date. ML weighing } \\
\text { capacity of } 7 \mathrm{~kg}\end{array}$ & Feigenwinter et al. (2020) \\
& $\begin{array}{l}\text { ML weighing capacity of } \\
20 \mathrm{~kg}\end{array}$ & This study \\
$\pm 0.005 \mathrm{~mm}$ & $\mathrm{ML}$ weighing capacity of 1 & Heusinkveld et al. (2006) \\
& $\mathrm{kg}$ & \\
$\pm 0.02 \mathrm{~mm}$ & & Zhang et al. (2019) \\
\hline $0.03 \mathrm{~mm}$ & &
\end{tabular}

\section{Precision of ML and LM}

\begin{tabular}{lll}
\hline $\pm 0.001 \mathrm{~g}( \pm 0.00012 \mathrm{~mm})$ & $\begin{array}{l}\text { ML pots were manually } \\
\text { weighed on an electronic } \\
\text { balance }\end{array}$ & Jia et al. $(2014)$ \\
$\pm 0.28 \mathrm{~g}( \pm 0.005 \mathrm{~mm})$ & & This study \\
$\pm 0.3 \mathrm{~g}( \pm 0.008 \mathrm{~mm})$ & $\begin{array}{l}\text { Precision ranged from } \pm \\
\text { (mean) }\end{array}$ & Feigenwinter et al. $(2020)$ \\
& $\begin{array}{l}1.12 \mathrm{~g}( \pm 0.002 \mathrm{~mm}) \text { to } \pm \\
\text { depending on calibration } \\
\text { date }\end{array}$ & \\
$\pm 20 \mathrm{~g}( \pm 0.01 \mathrm{~mm}$ to \pm 0.04 & $\begin{array}{l}\text { For a surface area of } 0.5 \\
\mathrm{~m}^{2} \text { up to } 2 \mathrm{~m}^{2}\end{array}$ & Meissner et al. $(2014)$ \\
$\mathrm{mm})$ & &
\end{tabular}

\section{Resolution of ML and LM}

\begin{tabular}{ll}
\hline $0.01 \mathrm{~g}( \pm 0.0002 \mathrm{~mm})$ & This study \\
$0.01 \mathrm{~g}( \pm 0.00055 \mathrm{~mm})$ & Uclés et al. $(2013)$ \\
$0.038 \mathrm{~g}( \pm 0.0026 \mathrm{~mm})$ & Kaseke et al. $(2012)$ \\
$0.1 \mathrm{~g}( \pm 0.0022 \mathrm{~mm})$ & Maphangwa et al. $(2012)$ \\
$0.1 \mathrm{~g}( \pm 0.004 \mathrm{~mm})$ & Agam and Berliner (2004) \\
\hline
\end{tabular}




\begin{tabular}{ll}
\hline $1 \mathrm{~g}$ and $10 \mathrm{~g}( \pm 0.001 \mathrm{~mm}$ & Big LM, two different LM Groh et al. (2018) \\
and $0.01 \mathrm{~mm})$ & $\begin{array}{l}\text { systems with } 1 \mathrm{~m}^{2} \text { surface } \\
\text { area }\end{array}$
\end{tabular}

\subsection{Quantification and differentiation among different types of NRW inputs}

NRW inputs occurred rather frequently over the entire year of observation (Fig. 8). NRW inputs could be measured on approximately one third of all days. The highest NRW inputs occurred during the months of main growth of grasslands (April-September), indicating a high hydro ecological relevance. Ancillary sensors allowed differentiation of different NRW inputs. The use of a visibility sensor allowed us to assess the contribution of fog and rime, although we could not estimate the water input ratios of dew, hoar frost and fog, rime during combined events. A leaf wetness sensor allowed differentiating between events in which condensation occurred (dew, hoar frost) in contrast to events when condensation on leaves was less probable (water vapor adsorption and/or dew formation on soil). Potential water vapor adsorption events occurred during periods with low rainfall, when soil was drying out, which increased the vapor pressure deficit gradient between soil and atmosphere, promoting water vapor adsorption. However, the NRW inputs of the potential water vapor adsorption events were with $<$ $1 \mathrm{~mm}$, and one event with $0.13 \mathrm{~mm}$ rather low. Thus, it is not unlikely that a leaf wetness sensor might react slightly different than a true plant leaf, despite the care that was taken to design leaf wetness sensors to match the radiative and thermodynamic properties of plant leaves, and these events were small dew events. Further investigations are needed to clarify if the leaf wetness sensor is suitable to differentiate between dew and water vapor adsorption events. Air temperature measurements from the agrometeorological station were necessary to differentiate between dew vs. hoar frost formation and between fog vs. rime. Rainfall measurements allowed differentiating between NRW events and rainfall events, and a networked digital camera allowed to observe persisting snow cover. The installation of three ML allowed exclusion of possible effects by insects, snails and lizards arriving on or departing from a ML pot. If it is assumed that these animals have no preference for a particular ML pot and thus their arrival and departure is a random process, such effects only contribute to the noise that is filtered out during data processing, and thus should not bias our NRW input estimates. The installation of multiple ML further had the advantage that spatial variation in soils, species composition and leaf area could be reduced in comparison to single ML deployments. Drainage water flow from the ML pots was not measured, which can be justified for applications during dry spells and drought periods, but clearly limits the application of our ML system during and shortly after rainfall periods. Under conditions with water lost via drainage flow, NRW inputs would be underestimated. At our site, drainage water flow from the ML pots reached low levels rather quickly after rainfall events (see Supplementary Material for more details). Nevertheless, under conditions when drainage water flow persists for a longer time, the ML system provides conservative estimates of NRW inputs. A possible modification of the ML system to also accurately quantify such drainage flow is suggested in the Supplementary Material. 
Our ML system had a larger area and a deeper pot than most other ML systems developed and used in earlier studies on NRW quantification (Table 3). This allowed unimpaired plant height growth (Fig. 6), representing more natural conditions than many, rather shallow ML systems, an issue crucial for accurate measurements of NRW inputs to short-statured vegetation. We did not find any differences in canopy temperatures between our ML pots and of the control (surrounding) (Fig. 5a). Furthermore, we found in general no significant difference in soil moisture between ML and the control (surrounding), only during a prolonged drought period soil moisture values of ML pots were decreasing faster. This had however no influence on plant growth, because measurements of plant height (before the drought period) and measurement of overall vegetation height (after the drought period) were not statistically different. Though, this can result in reduced evaporation rates and increased water vapor adsorption rates. WFPS values of ML pots were in general not higher than the control, suggesting a sufficient drainage by the drainage-water outlets. This is crucial, because saturation at the bottom of ML could lead to oxygen limitation for root growth (Ben-Gal and Shani, 2002). In contrast to Kidron and Kronenfeld (2017), Evett et al. (1995) and Ninari and Berliner (2002), we also did not observe substantially lower nocturnal soil temperatures, the time when NRW inputs actually take place, which is important to avoid an overestimation of dew formation on soils. On the other hand, afternoon and close to sunset soil temperatures of ML pots were higher compared to those in the control (Fig. 7). Thus, potentially, the ML system could underestimate dew formation on soils shortly after sunset, but dew formation on soils is rare (Agam and Berliner, 2004; Ninari and Berliner, 2002), the open soil surface in grasslands is rather small, ideally zero under good management practices. Higher soil temperatures could underestimate water vapor adsorption, because it lowers the vapor pressure deficit between soil and atmosphere. Therefore, our estimates of NRW inputs on soils should be conservative estimates, given that the slightly elevated temperatures actually do reduce (not increase) NRW inputs on soil inside the ML pots. The higher soil temperatures in the afternoon were not related to a lower water 605 content nor its associated heat capacity. Kidron et al. (2016) provided a possible explanation for the diurnal temperature difference between a ML pot and the control. They termed it a "loose stone effect", the ML pot might act as loose stone, i.e., through the air gap between the ML pot and the outer part of the ML system more efficient longwave radiational cooling can occur in comparison to the bulk soil. However, Ninari and Berliner (2002) found that the lateral soil temperature gradient was small 610 compared to the vertical soil temperature gradient and that wrapping the ML pots with insulation material did not reduce temperature deviations. We thus think that insufficient ML pot depth has most likely caused the soil temperature alterations observed mainly during daytime when dew formation is absent. Ninari and Berliner (2002) suggested that the minimum ML depth should be the depth at which the temperature is constant during the entire day. For a dry loess soil in the Negev Desert, a sufficient

615 ML pot depth would be $50 \mathrm{~cm}$ (Ninari and Berliner, 2002). At CH-FRU, a ML pot depth of approximately $95 \mathrm{~cm}$ would be necessary, in order to have soil temperature gradients over 24-hour periods $<0.5^{\circ} \mathrm{C}$. With a depth of $95 \mathrm{~cm}$, there would be the risk that all the advantages any ML system entails would be lost. Although constructing deeper ML pots would be possible, even with double or triple the current ML pot depth, deeper ML pots would exert more dead mass onto the load cell and would thus decrease load cell accuracy (Kaseke et al., 2012). Overall, ML design is always a tradeoff 
between representing the surrounding and feasibility of construction and installation. The ML system was not constructed with the depth suggested by Ninari and Berliner (2002), however, the aim of this study was to measure NRW inputs to grasslands, for which canopy temperatures are more important. We found only a small difference in canopy temperature between ML and the control. Thus, we 625 conclude that our novel ML design is suitable for quantifying nocturnal NRW inputs on plants reliably and accurately at high temporal resolution. 
Table 3. Size comparison of lysimeters (LM) and micro-lysimeters (ML) developed and used for NRW studies.

\begin{tabular}{|c|c|c|c|c|c|}
\hline $\begin{array}{l}\text { LM } \\
\text { or } \\
\text { ML }\end{array}$ & $\begin{array}{l}\text { Depth } \\
\text { [cm] }\end{array}$ & $\begin{array}{l}\text { Diamet } \\
\text { er }[\mathbf{c m}]\end{array}$ & Study object & Locality & Reference \\
\hline LM & 150 & 112 & grassland & $\begin{array}{l}\text { Gumpenstein, } \\
\text { Rollesbroich } \\
\text { (Austria and } \\
\text { Germany) }\end{array}$ & $\begin{array}{l}\text { Groh et al. } \\
\text { (2018) }\end{array}$ \\
\hline LM & 200 & 112 & cropland (Zea mays) & $\begin{array}{l}\text { Helmholtz } \\
\text { Centre for } \\
\text { Environmental } \\
\text { Research - UFZ } \\
\text { (Germany) }\end{array}$ & $\begin{array}{l}\text { Meissner et al. } \\
\text { (2007) }\end{array}$ \\
\hline LM & 265 & 225 & herbaceous vegetation & Dingxi (China) & $\begin{array}{l}\text { Zhang et al. } \\
\text { (2019) }\end{array}$ \\
\hline ML & 3.5 & 6 & sand dunes & $\begin{array}{l}\text { Nizzana, Negev } \\
\text { desert (Israel) }\end{array}$ & $\begin{array}{l}\text { Jacobs et al. } \\
\text { (1999) }\end{array}$ \\
\hline ML & 3.5 & 6 & $\begin{array}{l}\text { undisturbed soil with } \\
\text { biological soil crusts }\end{array}$ & $\begin{array}{l}\text { Gurbantunggut } \\
\text { desert (China) }\end{array}$ & $\begin{array}{l}\text { Zhang et al. } \\
\text { (2009) }\end{array}$ \\
\hline ML & 3.5 & 8.8 & soil & $\begin{array}{l}\text { Knersvlakte } \\
\text { (South Africa) }\end{array}$ & $\begin{array}{l}\text { Brown et al. } \\
(2008)\end{array}$ \\
\hline ML & 3.5 & 14 & sand & $\begin{array}{l}\text { Nizzana, Negev } \\
\text { desert (Israel) }\end{array}$ & $\begin{array}{l}\text { Heusinkveld et } \\
\text { al. (2006) }\end{array}$ \\
\hline ML & 3.5 & 14 & river sand & $\begin{array}{l}\text { Stellenbosch } \\
\text { (South Africa) }\end{array}$ & $\begin{array}{l}\text { Kaseke et al. } \\
(2012)\end{array}$ \\
\hline ML & 3.5 & 24 & $\begin{array}{l}\text { gypsum soils and } \\
\text { lichens }\end{array}$ & $\begin{array}{l}\text { Alexander bay } \\
\text { (South Africa) }\end{array}$ & $\begin{array}{l}\text { Maphangwa et } \\
\text { al. (2012) }\end{array}$ \\
\hline ML & 3.5 & 24 & dwarf succulents & $\begin{array}{l}\text { Quaggaskop, } \\
\text { Knersvlakte } \\
\text { (South Africa) }\end{array}$ & $\begin{array}{l}\text { Matimati et al. } \\
\text { (2013) }\end{array}$ \\
\hline ML & 6.5 & 25 & bare soil & $\begin{array}{l}\text { Central Namib } \\
\text { Desert (Africa) }\end{array}$ & $\begin{array}{l}\text { Feigenwinter } \\
\text { et al. }(2020)\end{array}$ \\
\hline
\end{tabular}




\begin{tabular}{|c|c|c|c|c|c|}
\hline ML & 9 & 15.2 & $\begin{array}{l}\text { bare soil with } \\
\text { biological soil crusts } \\
\text { and the grass Stipa } \\
\text { tenecissima }\end{array}$ & $\begin{array}{l}\text { Balsa Blanca } \\
\text { and El Cautivo } \\
\text { (Spain) }\end{array}$ & $\begin{array}{l}\text { Uclés et al. } \\
\text { (2013) }\end{array}$ \\
\hline ML & $\begin{array}{l}15 \text { and } \\
55\end{array}$ & $\begin{array}{l}25 \text { and } \\
18.6\end{array}$ & $\begin{array}{l}\text { soil with biological } \\
\text { soil crusts }\end{array}$ & $\begin{array}{l}\text { Wadi Mashash } \\
\text { Experimental } \\
\text { Farm, Negev } \\
\text { desert (Israel) }\end{array}$ & $\begin{array}{l}\text { Ninari and } \\
\text { Berliner } \\
(2002)\end{array}$ \\
\hline ML & 25 & 25 & grassland & $\begin{array}{l}\text { Früebüel } \\
\text { (Switzerland) }\end{array}$ & This study \\
\hline
\end{tabular}

\subsection{NRW inputs at CH-FRU}

NRW inputs occurred on approximately one third of the nights and were thus a frequent water input. NRW inputs were especially high under conditions when rainfall was absent, e.g. in April, the month with the lowest rainfall. NRW inputs were not influenced by potential NRW input duration, thus there was also a high probability for NRW inputs to occur during summer months, the main growth period of temperate grasslands. In fact, the monthly average NRW inputs were similar to the NRW inputs that were measured in spring and autumn months, when NRW inputs are expected to be highest. This indicates a high ecohydrological relevance of NRW inputs for temperate grassland ecosystems, especially during hot and dry periods. However, the effects of these frequent NRW inputs on plant water status have still to be investigated.

675 Besides studying the effects of NRW inputs on temperate grassland species during hot days with low soil moisture, a special focus should be directed to the effects of NRW inputs during periods with high soil moisture, when no soil water stress is present. NRW inputs could be beneficial even under such conditions, when simultaneously atmospheric demand is high (high energy input, high vapor pressure deficit). NRW inputs could reduce leaf temperatures by the re-evaporative cooling effect and thereby reduce water stress during early morning hours and consequently increase productivity (Dawson and Goldsmith, 2018). However, leaf wetting by NRW inputs could also be disadvantageous during periods with no soil water stress. Leaves covered by water droplets from NRW inputs could show reduced gas exchange due to lower gas diffusivity through the water layer. Thus, the development of the ML system and measuring NRW inputs with high accuracy are crucial steps to address ecohydrological processes, but further investigations are necessary to understand physiological effects on grasslands.

\section{Summary and conclusions}

The aim of this study was to develop a high accuracy ML system for the quantification of NRW inputs that overcomes existing drawbacks. The ML system comprised a comparatively large and deep ML pot in the size class of $25 \times 25 \mathrm{~cm}$ in combination with an unprecedented weighing accuracy. This ML size 
690 allowed natural plant growth and such a ML system can therefore be used in different ecosystems with most short to mid-size statured vegetation up to $120 \mathrm{~cm}$. Ancillary sensors allowed differentiating among different types of NRW inputs. However, further methodical improvements are necessary to distinguish between the fraction of dew, hoar frost and fog, rime water inputs during combined events. Our study showed that the ML system simulated natural conditions very well. The plant height was not

695 significantly different between ML pots and the control (surrounding). Plant canopy temperatures of ML pots were close to canopy temperatures of the surrounding during a nocturnal period when NRW input took place. However, additional continuous canopy temperature measurements in follow-up studies could allow to more clearly distinguish dew formation from water vapor adsorption and to identify if canopy temperature drops below dewpoint temperature. If this is not the case, and other

700 factors like rainfall and fog can be excluded, a weight increase might then be related to water vapor adsorption. Furthermore, canopy temperature measurements would clarify if a leaf wetness sensor alone is sufficient to distinguish between dew and water vapor adsorption events. In addition, the ML system could be further improved by adding water flow or water droplet sensors at the ML pot outlets to measure drainage water flow (see Supplementary Material), with the goal to avoid underestimation of

705 NRW inputs shortly after intensive rainfall events. With our ML system, we were able to resolve mass changes on a $15 \mathrm{~kg}$ pot with an accuracy of $\pm 0.25 \mathrm{~g}$, which corresponds to $\pm 0.005 \mathrm{~mm}$ of water input. This accuracy allows determining typical water gains by dew, hoar frost, fog, rime or water vapor adsorption on the order of 0.021 to $0.4 \mathrm{~mm}$ in a single night. The study revealed that, NRW inputs occurred frequently and provided on average of all NRW events $0.12 \mathrm{~mm}$ of water. Such quantitative

710 estimates will be essential to assess the role that NRW inputs might have on temperate grasslands during summer drought conditions. However, longer-term NRW input measurements would allow to see whether the seasonal pattern of NRW inputs are constant over time, or if they are influenced by weather conditions and thus vary from season to season. Moreover, the effects of NRW inputs on plant physiology in grassland ecosystems have still to be elucidated more carefully, to assess the importance

715 of such water inputs during ongoing climate change such as projected prolonged heat periods in the months of main vegetation growth.

\section{Appendix A: Drainage water flow of ML pots}

The ML pots were designed to avoid stagnation of water that potentially could impede plant growth by creating anaerobic conditions in the rooting zone. For that reason, a passive drainage water flow path allowed drainage of excess water beyond field capacity. However, to further develop this ML system and use it more universally, it is recommended to quantify drainage water flow. This is because NRW inputs increase the mass of ML pots, whereas drainage water flow out of the ML pots reduces their mass. Therefore, if drainage water flow during NRW inputs is non-zero, this would lead to an underestimation of the NRW inputs, as long as no additional sensor is added to the ML pots to quantify

725 this drainage flow.

To assess the required specification of such an additional sensor and to quantify how long drainage water flow of the ML system persists, we investigated three consecutive events:

1) A high intensity, high amount and high duration rainfall event (Fig. S1a, event 1); 
2) an evapotranspiration event from sunrise until sunset (Fig. S1a, event 2), and

3) a NRW input event (Fig. S1a, event 3).

Event 1 lasted for 20 hours and 24 minutes, started on 28 July 2019 at 06:03 UTC and ended on 29 July 2019 at 02:27 UTC. Event 2 lasted 15 hours and 2 minutes, started on 29 July 04:00 UTC and ended on July 29 at 19:02 UTC. Event 3 lasted for 8 hours and 41 minutes, started on July 29 at 21:18 and ended on July 30 at 6:17 UTC. Local times (CEST) are 2 hours ahead of UTC at this location.

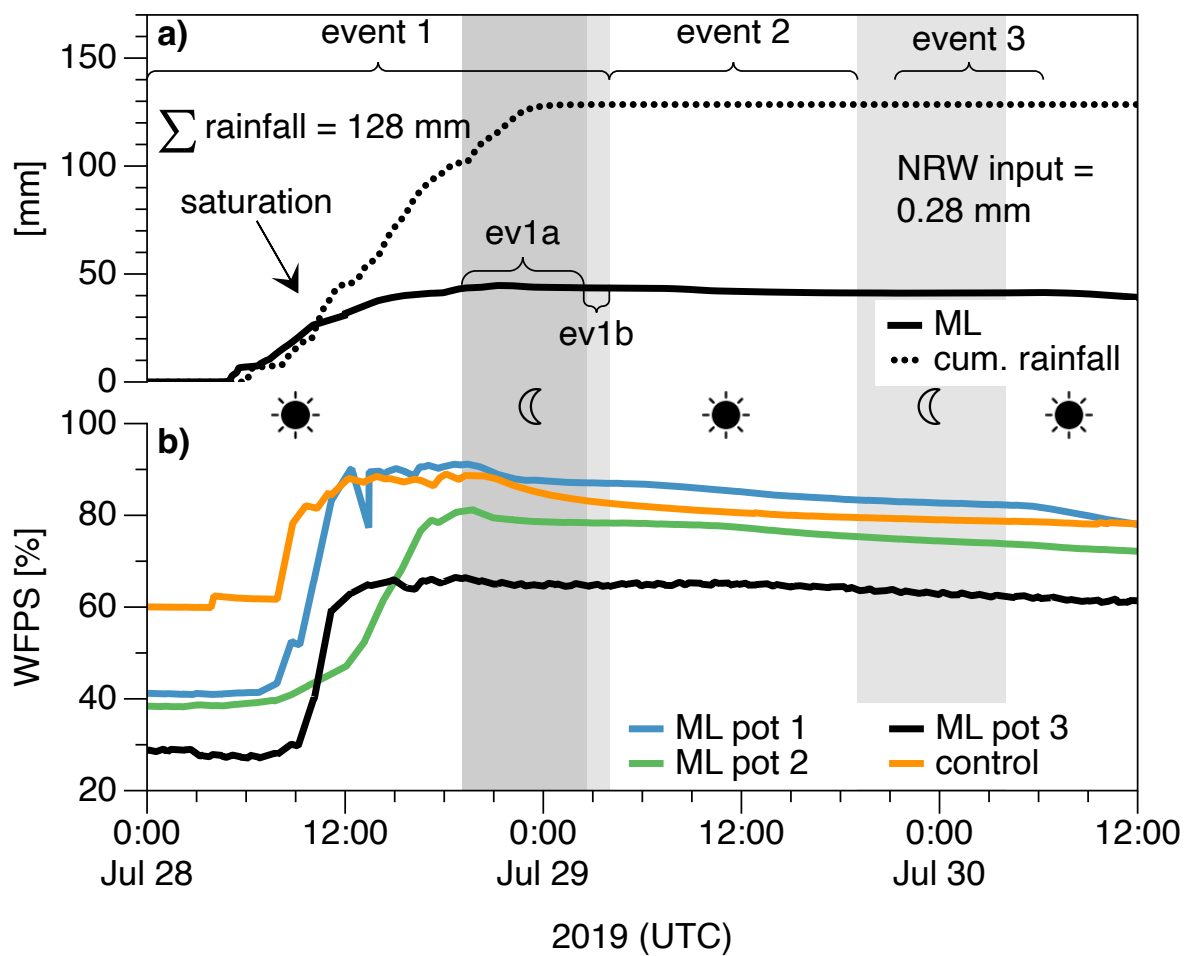

Fig. A1. (a) Cumulative rainfall and ML mass during a rainfall (event 1), an evapotranspiration (event 2) and a NRW event (event 3), from July 28 00:00 until July 30 12:00 UTC. The grey-shaded areas indicate nighttime duration (sunset until sunrise), the unshaded areas indicate daytime (sunrise until sunset). The ML mass and the cumulative rainfall increased with the same rate until the ML pots were almost saturated (indicated with an arrow). Afterwards there was more drainage water lost from the ML pots than water gained. During the ev1a period (from sunset until the end of rainfall in event1), a rainfall water input of 26.9 mm was observed, but the ML system showed a water gain of only $0.3 \mathrm{~mm}$, the difference between the two measurements corresponds to the (unmeasured) loss via drainage water flow. During the ev1b period (from the end of rainfall until sunrise in event1), there was no rainfall water input, but the ML system showed a water loss of $0.07 \mathrm{~mm}$. During event 2 there was a water loss by evapotranspiration of $2.25 \mathrm{~mm}$. During event 3 (the following night), there was no water loss, but instead a water gain by NRW

745 input of $0.28 \mathrm{~mm}$. (b) WFPS inside the ML pots and the control, measured at a depth of $15 \mathrm{~cm}$. WFPS reached high values after the rainfall event.

During event 1 , the total amount of rainfall was $128.5 \mathrm{~mm}$. The highest hourly rainfall intensity occurred on 28 July 2019 at 10 UTC with $16.8 \mathrm{~mm} \mathrm{~h}^{-1}$, which classifies as "heavy rain" $>4 \mathrm{~mm} \mathrm{~h}^{-1}$ (Met Office, 2012). ML mass increased as soon as the rainfall event started and increased with the same rate during the rainfall input until ca. 11 UTC. Afterwards the rate of ML mass change, i.e. the slope of the ML mass increase was flattening compared to the cumulative curve of rainfall input: From the beginning of the rainfall event until sunset, the water input was $101.6 \mathrm{~mm}$, whereas the ML system 
showed an increase of only $36.2 \mathrm{~mm}$. The difference of $65.4 \mathrm{~mm}$ most likely corresponds to the losses from drainage water flow, because of soil saturation during such high intensity rainfall with excessive water being lost. However, WFPS did not reach the $100 \%$ mark (Fig. S1b). Note that the $100 \%$ WFPS reference was determined from the full year of measurements and is thus relative to spring conditions. Therefore, it is not surprising that this mark was never reached during dry summers, even after heavy precipitation. During such a high rainfall water input, drainage water flow of the ML system was on the order of $64 \%$ of the rainfall amount. However, water might not only be lost via drainage water flow, but also by evapotranspiration during daytime. To quantify solely drainage water loss, the nighttime period (when no evapotranspiration is expected) was further investigated. We separated the nighttime period in period evla, when rainfall occurred, and period evlb, when no rainfall occurred (Fig. S1a, gray shaded periods). During the ev1a period (Fig. S1a, period ev1a), from sunset until the end of the rainfall event, the water input was $26.9 \mathrm{~mm}$, whereas the ML system showed only an increase of 0.3 $\mathrm{mm}$. The difference of $26.6 \mathrm{~mm}(98 \%)$ might be caused by losses from drainage water flow. The water loss rate was $3.6 \mathrm{~mm} \mathrm{~h}^{-1}$. The $34 \%$ higher drainage water loss compared to the daytime period might be due to the lower water holding capacity of the more saturated soil. During the ev1b period, starting after the evla period until sunrise (Fig. S1a, period ev1b), no further water gains and losses were expected, because evapotranspiration was absent during nocturnal conditions with low average wind speed $(<0.6$

$770 \mathrm{~m} \mathrm{~s}^{-1}$ ). During period ev1b, the ML system showed a water loss of $0.07 \mathrm{~mm}$, which corresponds to an average water loss of $0.05 \mathrm{~mm} \mathrm{~h}^{-1}$. This water loss can clearly be attributed to drainage water flow. The rate of drainage water loss was however strongly reduced (by 98\%) compared to the evla period. Thus, drainage water flow of the ML system reached very low values within only 1 hour and 33 minutes after this extraordinary high rainfall, showing that even the current ML system can handle high drainage

775 water flows well.

During event 2 with no rain but evapotranspiration, the ML system indicated a water loss of $2.25 \mathrm{~mm}$, which corresponds to an average evapotranspiration rate of $0.15 \mathrm{~mm} \mathrm{~h}^{-1}$. Potentially a drainage water loss could have occurred in the morning hours on July 29. However, the drainage water loss most likely was $<0.05 \mathrm{~mm} \mathrm{~h}^{-1}$, similar to the drainage water flow rate during the ev1b period, just before event 2 . shortly after the rainfall event. Since no new rain fell, we expect the drainage water flow rate to decrease with time. In fact, one hour before sunset, a further reduced ML mass loss of only $0.005 \mathrm{~mm} \mathrm{~h}^{-}$ ${ }^{1}$ was recorded. This very low water loss can be either attributed to drainage water loss, or to evapotranspiration as it occurred during daytime. We conclude that the drainage water loss could at maximum be $0.005 \mathrm{~mm} \mathrm{~h}^{-1}$, but was most likely lower due to concurrent evapotranspiration. Thus, the

785 ML system readings were no longer significantly affected by potential drainage water flow after only 15 hours after rainfall.

During event 3 , a very large dew event of $0.28 \mathrm{~mm}$ occurred, which was above the $95^{\text {th }}$ percentile of all NRW events during the 12 months period considered in this study. Such a large dew event is unlikely to be recorded under conditions when at the same time also a large drainage water flow would have

790 occurred. If this would have happened, the dew water input should have been lower. Thus, it is very unlikely that drainage water flow still occurred during that dew event.

Overall, these three events showed that drainage flow can occur under rainfall conditions and shortly after rainfall events. The current ML system handled large drainage flows well and effectively, i.e. water drained fast, avoiding long-lasting "memory" effects. Nevertheless, if the current ML system 
795 were to be used for high rainfall conditions, potential drainage water flow need to be quantified using additional sensors. Without such additional sensors, NRW inputs could be underestimated if the NRW input occurs shortly after a rainfall event and drainage water flow indeed occurs. Consequently, the current ML system is expected to give conservative estimates of NRW inputs, especially if NRW inputs happen directly after a rainfall event.

800 To further develop the usability of the current ML system for conditions with abundant rainfall, we suggest to continuously measure drainage water outflow. The amounts of drainage water flow from the pot size used in this ML are however too small for using conventional tipping bucket devices which would work adequately with large lysimeters. Suited approaches to quantify the small amounts of drainage flow from a ML system are by installing a water flow sensor or a drip counter at the ML pot drainage water outlets, or by adding an additional weighing platform to the ML system, on which drainage water is collected and continuously measured. The maximum rainfall intensity reported above was $16.8 \mathrm{~mm} \mathrm{~h}^{-1}$. With a pot diameter of $25 \mathrm{~cm}$ (see Section 2.2.1 of the main text), and the extreme assumption that $100 \%$ of precipitation contributes to drainage water flow, such an addition must be able to process $13.7 \mathrm{ml} \mathrm{min}^{-1}$. If the maximum drainage water flow is however only expected to be $<15 \%$ of 810 precipitation, then a sensor capable of measuring up to $2000 \mu 1 \mathrm{~min}^{-1}$ would be an adequate choice. An additional weighing platform would increase costs and maintenance labor substantially. We thus recommend using a water flow sensor or a drip counter instead. One option is a liquid flow sensor (SLF3S-0600F, Sensirion AG, Staefa, Switzerland) that is capable to detect low flow rates of up to $\pm 2000 \mu 1 \mathrm{~min}^{-1}$. A drip counter can be constructed with two gold electrodes attached to the ML pots 815 drainage water holes with a small gap. If a water droplet passes the gap, an electric circuit is closed which can be counted as a water drop by a datalogger (Meter Group AG, 2020). Calibration of a drip counter is recommended for accurate measurements of drainage water amount. Sensors measuring drainage water flow would allow to correct for drainage water outflow and would thereby increase the usability of the current ML system for times during and shortly after rainfall events. 
Appendix B: NRW inputs vs. nighttime duration

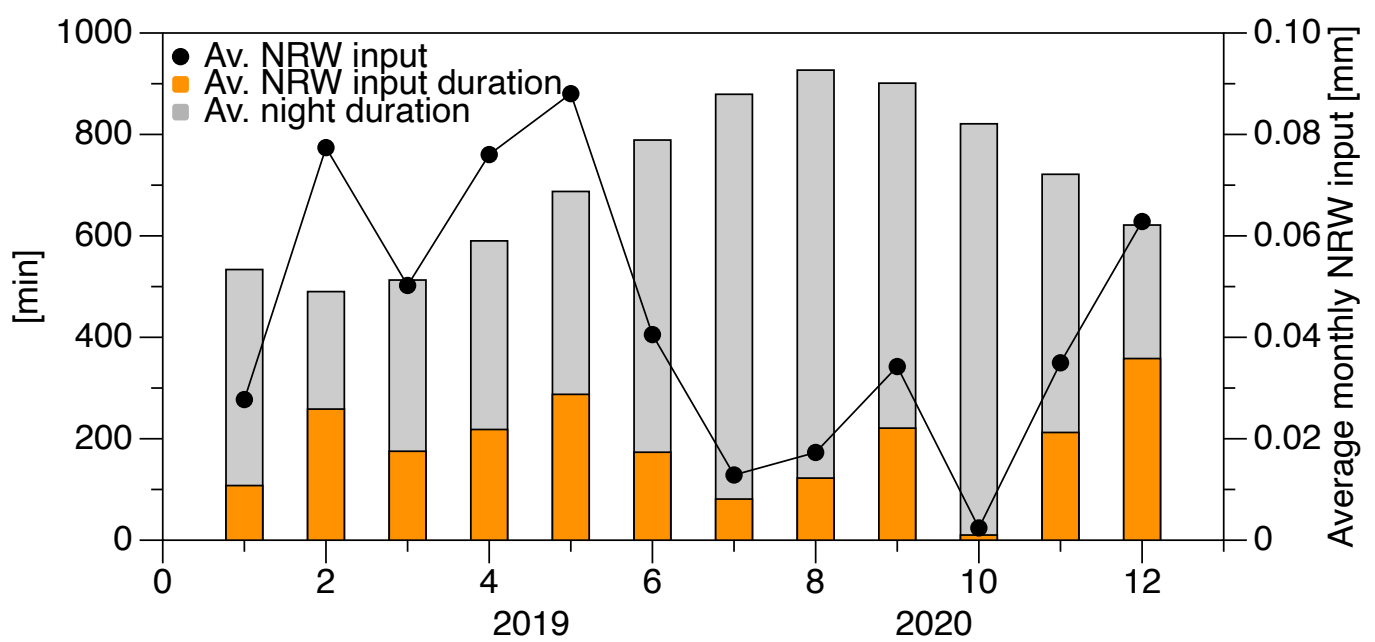

Fig. A2. Average monthly NRW input with average monthly NRW input duration and average night duration (potential NRW input duration).

825 Data availability. Data were stored at the ETH Zurich research collection at: https://doi.org/10.3929/ethzb-000488747 (Riedl, 2021).

Author contribution. AR and WE designed the ML system. AR built the ML system and installed it together with YL. AR carried out maintenance, experiments, data collection and data analysis. NB, WE commented on the results of data analysis. AR wrote and revised the manuscript, with contributions and feedbacks by YL, NB and WE.

Competing interests. The authors declare that they have no conflict of interest.

835 Acknowledgements. We are grateful to Paul Linwood for his excellent work with electronics and installation assistance in the field, and we thank Markus Staudinger, Philip Meier and Thomas Baur for their technical support. We also thank Patrick Flütsch for constructing the ML pots and lids.

Financial support. This research was founded by the Swiss National Science Foundation (grant no. 175733).

\section{References}

Agam, N. and Berliner, P. R.: Diurnal water content changes in the bare soil of a coastal desert, J. Hydrometeorol., 5(5), 922-933, doi:10.1175/1525-7541(2004)005<0922:DWCCIT>2.0.CO;2, 2004.

Agam, N. and Berliner, P. R.: Dew formation and water vapor adsorption in semi-arid environmentsA review, J. Arid Environ., 65(4), 572-590, doi:10.1016/J.JARIDENV.2005.09.004, 2006. 
Aparecido, L. M. T., Miller, G. R., Cahill, A. T. and Moore, G. W.: Comparison of tree transpiration under wet and dry canopy conditions in a Costa Rican premontane tropical forest, Hydrol. Process., 30(26), 5000-5011, doi:10.1002/hyp.10960, 2016.

Ben-Gal, A. and Shani, U.: A highly conductive drainage extension to control the lower boundary condition of lysimeters, Plant Soil, 239(1), 9-17, doi:10.1023/A:1014942024573, 2002.

Berry, Z. C., White, J. C. and Smith, W. K.: Foliar uptake, carbon fluxes and water status are affected by the timing of daily fog in saplings from a threatened cloud forest, Tree Physiol., 34(5), 459470, doi:10.1093/treephys/tpu032, 2014.

Beysens, D.: Dew water, River Publishers, Gistrup Denmark., 2018.

855 Boucher, J. F., Munson, A. D. and Bernier, P. Y.: Foliar absorption of dew influences shoot water potential and root growth in Pinus strobus seedlings, Tree Physiol., 15(12), 819-823, doi:10.1093/treephys/15.12.819, 1995.

Brown, R., Mills, A. J. and Jack, C.: Non-rainfall moisture inputs in the Knersvlakte: Methodology and preliminary findings, Water SA, 34(2), 275-278, doi:10.4314/wsa.v34i2.183649, 2008.

Chen, L., Meissner, R., Zhang, Y. and Xiao, H.: Studies on dew formation and its meteorological factors, J. Food, Agric. Environ., 11(2), 1063-1068 [online] Available from: https:/cache.1science.com/4a/c8/4ac89aab9e197407866730c777f8d2946d5b2089.pdf (Accessed 23 April 2018), 2005.

Dawson, T. E.: Fog in the California redwood forest: ecosystem inputs and use by plants, Oecologia, 117(4), 476-485, doi:https://doi.org/10.1007/s004420050683, 1998.

Dawson, T. E. and Goldsmith, G. R.: The value of wet leaves, New Phytol., 219(4), 1156-1169, doi:10.1111/nph.15307, 2018.

Eller, C. B., Lima, A. L. and Oliveira, R. S.: Foliar uptake of fog water and transport belowground alleviates drought effects in the cloud forest tree species, Drimys brasiliensis (Winteraceae), New Phytol., 199(1), 151-162, doi:10.1111/nph.12248, 2013.

Engle, R. F. and Granger, C. W. J.: Co-Integration and Error Correction: Representation, Estimation, and Testing, Econometria, 55(2), 251-276, doi:10.2307/1913236, 1987.

Eugster, W., Burkard, R., Holwerda, F., Scatena, F. N. and Bruijnzeel, L. A. (Sampurno.: Characteristics of fog and fogwater fluxes in a Puerto Rican elfin cloud forest, Agric. For. Meteorol., 139(3-4), 288-306, doi:10.1016/J.AGRFORMET.2006.07.008, 2006.

Evett, S. R., Warrick, A. W. and Matthias, A. D.: Wall Material and Capping Effects on Microlysimeter Temperatures and Evaporation, Soil Sci., 59(2), 329-336, 1995.

Feigenwinter, C., Franceschi, J., Larsen, J. A., Spirig, R. and Vogt, R.: On the performance of microlysimeters to measure non-rainfall water input in a hyper-arid environment with focus on fog contribution, J. Arid Environ., 182, 1-13, doi:10.1016/j.jaridenv.2020.104260, 2020.

Fischer, E. and Schär, C.: 6. Climate extremes and climate indices. In: CH2018 (2018), CH2018 Climate Scenarios for Switzerland, , Technical Report, , 140, 2018.

Gerlein-Safdi, C., Koohafkan, M. C., Chung, M., Rockwell, F. E., Thompson, S. and Caylor, K. K.: Dew deposition suppresses transpiration and carbon uptake in leaves, Agric. For. Meteorol., 259, 305-316, doi:10.1016/j.agrformet.2018.05.015, 2018.

Groh, J., Slawitsch, V., Herndl, M., Graf, A., Vereecken, H. and Pütz, T.: Determining dew and hoar frost formation for a low mountain range and alpine grassland site by weighable lysimeter, J. 
Hydrol., 563, 372-381, doi:10.1016/J.JHYDROL.2018.06.009, 2018.

Heusinkveld, B. G., Berkowicz, S. M., Jacobs, A. F. G., Holtslag, A. A. M. and Hillen, W. C. A. M.: An automated microlysimeter to study dew formation and evaporation in arid and semiarid regions, J. Hydrometeorol., 7(4), 825-832, doi:10.1175/JHM523.1, 2006.

Imer, D., Merbold, L., Eugster, W. and Buchmann, N.: Temporal and spatial variations of soil $\mathrm{CO}_{2}, \mathrm{CH}_{4}$ and $\mathrm{N}_{2} \mathrm{O}$ fluxes at three differently managed grasslands, Biogeosciences, 10(9), 5931-5945, doi:10.5194/bg-10-5931-2013, 2013.

895 Ishibashi, M. and Terashima, I.: Effects of continuous leaf wetness on photosynthesis: adverse aspects of rainfall, Plant. Cell Environ., 18(4), 431-438, doi:10.1111/j.1365-3040.1995.tb00377.x, 1995.

Jacobs, A. F. G., Heusinkveld, B. G. and Berkowicz, S. M.: Dew deposition and drying in a desert system: A simple simulation model, J. Arid Environ., 42(3), 211-222, doi:10.1006/jare.1999.0523, 1999.

900 Jacobs, A. F. G., Heusinkveld, B. G., Wichink Kruit, R. J. and Berkowicz, S. M.: Contribution of dew to the water budget of a grassland area in the Netherlands, Water Resour. Res., 42(3), doi:10.1029/2005WR004055, 2006.

Jia, R. liang, Li, X. rong, Liu, L. chao, Pan, Y. xia, Gao, Y. hong and Wei, Y. ping: Effects of sand burial on dew deposition on moss soil crust in a revegetated area of the Tennger Desert,

905 Northern China, J. Hydrol., 519(PB), 2341-2349, doi:10.1016/j.jhydrol.2014.10.031, 2014.

Kaseke, K. F., Mills, A. J., Brown, R., Esler, K. J., Henschel, J. R. and Seely, M. K.: A Method for Direct Assessment of the "Non Rainfall" Atmospheric Water Cycle: Input and Evaporation From the Soil, Pure Appl. Geophys., 169(5-6), 847-857, doi:10.1007/s00024-011-0328-9, 2012.

Kerr, J. P. and Beardsell, M. F.: Effect of Dew on Leaf Water Potentials and Crop Resistances in a Paspalum Pasture, Agron. J., 67(5), 596-599, doi:10.2134/agronj1975.00021962006700050002x, 1975.

Kidron, G. J. and Kronenfeld, R.: Assessing the effect of micro-lysimeters on NRWI: Do microlysimeters adequately represent the water input of natural soil?, J. Hydrol., 548, 382-390, doi:10.1016/j.jhydrol.2017.03.005, 2017.

915 Kidron, G. J. and Starinsky, A.: Measurements and ecological implications of non-rainfall water in desert ecosystems-A review, Ecohydrology, 12(6), doi:10.1002/eco.2121, 2019.

Kidron, G. J., Kronenfeld, R. and Starinsky, A.: Wind as a cooling agent: substrate temperatures are responsible for variable lithobiont-induced weathering patterns on west- and east-facing limestone bedrock of the Negev, Earth Surf. Process. Landforms, 41(14), 2078-2084,

920 doi:10.1002/esp.3973, 2016.

Limm, E., Simonin, K., Bothman, A. and Dawson, T.: Foliar water uptake: a common water acquisition strategy for plants of the redwood forest, Oecologia, 161(3), 449-459, doi:https://doi.org/10.1007/s00442-009-1400-3, 2009.

Maphangwa, K. W., Musil, C. F., Raitt, L. and Zedda, L.: Differential interception and evaporation of fog, dew and water vapour and elemental accumulation by lichens explain their relative abundance in a coastal desert, J. Arid Environ., 82, 71-80, doi:10.1016/j.jaridenv.2012.02.003, 2012.

Matimati, I., Musil, C. F., Raitt, L. and February, E.: Non rainfall moisture interception by dwarf succulents and their relative abundance in an inland arid South African ecosystem, 
Ecohydrology, 6(5), 818-825, doi:10.1002/eco.1304, 2013.

McHugh, T. A., Morrissey, E. M., Reed, S. C., Hungate, B. A. and Schwartz, E.: Water from air: An overlooked source of moisture in arid and semiarid regions, Sci. Rep., 5, doi:10.1038/srep13767, 2015.

Meissner, R., Seeger, J., Rupp, H., Seyfarth, M. and Borg, H.: Measurement of dew, fog, and rime with a high-precision gravitation lysimeter, J. Plant Nutr. Soil Sci., 170(3), 335-344, doi:10.1002/jpln.200625002, 2007.

Meissner, R., Rupp, H. and Seyfarth, M.: Advanced technologies in lysimetry, Environ. Sci. Eng. (Subseries Environ. Sci., (202979), 159-173, doi:10.1007/978-3-319-01017-5_8, 2014.

MeteoSchweiz: Klimabulletin Jahr 2019 [WWW Document]. URL https://www.meteoschweiz.admin.ch/content/dam/meteoswiss/de/service-undpublikationen/Publikationen/doc/2019_ANN_d.pdf (accessed 2020-05-01), 2020.

Meter Group AG, 2020. Atmos 41. [WWW Document]. URL http://library.metergroup.com/Manuals/20635_ATMOS41_Manual_Web.pdf (accessed 02.04.2021).

Met Office, 2012. National Meteorological Library and Archive Fact Sheet 3 - Water in the atmosphere. [WWW Document]. URL

https://www.metoffice.gov.uk/binaries/content/assets/metofficegovuk/pdf/research/library-andarchive/library/publications/factsheets/factsheet_3-water-in-the-atmosphere.pdf (accessed 02.04.2021).

Minnis, P.: Asymmetry in the diurnal variation of surface albedo, IEEE Trans. Geosci. Remote Sens., 35(4), 879-891, doi:10.1109/36.602530, 1997.

Monteith, J. L.: Dew, Q. J. R. Meteorol. Soc., 83(357), 322-341, doi:10.1002/qj.49708335706, 1957.

Munné-Bosch, S. and Alegre, L.: Role of Dew on the Recovery of Water-Stressed Melissa officinalis L. Plants, J. Plant Physiol., 154(5-6), 759-766, doi:10.1016/S0176-1617(99)80255-7, 1999.

Ninari, N. and Berliner, P. R.: The role of dew in the water and heat balance of bare loess soil in the Negev Desert: Quantifying the actual dew deposition on the soil surface, Atmos. Res., 64, 323334, doi:10.1016/S0169-8095(02)00102-3, 2002.

Pastorello, G., Trotta, C., Canfora, E., Chu, H., Christianson, D., Cheah, Y. W., Poindexter, C., Chen, J., Elbashandy, A., Humphrey, M., Isaac, P., Polidori, D., Ribeca, A., van Ingen, C., Zhang, L., Amiro, B., Ammann, C., Arain, M. A., Ardö, J., Arkebauer, T., Arndt, S. K., Arriga, N., Aubinet, M., Aurela, M., Baldocchi, D., Barr, A., Beamesderfer, E., Marchesini, L. B., Bergeron, O., Beringer, J., Bernhofer, C., Berveiller, D., Billesbach, D., Black, T. A., Blanken, P. D., Bohrer, G., Boike, J., Bolstad, P. V., Bonal, D., Bonnefond, J. M., Bowling, D. R., Bracho, R., Brodeur, J., Brümmer, C., Buchmann, N., Burban, B., Burns, S. P., Buysse, P., Cale, P., Cavagna, M., Cellier, P., Chen, S., Chini, I., Christensen, T. R., Cleverly, J., Collalti, A., Consalvo, C., Cook, B. D., Cook, D., Coursolle, C., Cremonese, E., Curtis, P. S., D’Andrea, E., da Rocha, H., Dai, X., Davis, K. J., De Cinti, B., de Grandcourt, A., De Ligne, A., De Oliveira, R. C., Delpierre, N., Desai, A. R., Di Bella, C. M., di Tommasi, P., Dolman, H., Domingo, F., Dong, G., Dore, S., Duce, P., Dufrêne, E., Dunn, A., Dušek, J., Eamus, D., Eichelmann, U., ElKhidir, H. A. M., Eugster, W., Ewenz, C. M., Ewers, B., Famulari, D., Fares, S., Feigenwinter, I., Feitz, A., Fensholt, R., Filippa, G., Fischer, M., Frank, J., Galvagno, M., 
Gharun, M., Gianelle, D., et al.: The FLUXNET2015 dataset and the ONEFlux processing pipeline for eddy covariance data, Sci. data, 7(1), 225, doi:10.1038/s41597-020-0534-3, 2020.

Richards, K.: Observation and simulation of dew in rural and urban environments, Prog. Phys. Geogr., 28(1), 76-94, doi:10.1191/0309133304pp402ra, 2004.

Ritter, A., Regalado, C. M. and Aschan, G.: Fog reduces transpiration in tree species of the Canarian relict heath-laurel cloud forest (Garajonay National Park, Spain), Tree Physiol., 29(4), 517-528, doi:10.1093/treephys/tpn043, 2009.

Sautier, S. C.: Zusammensetzung und Produktivität der Vegetation im Gebiet der ETHZForschungsstation Früebüel (ZG), MSc Thesis, Inst. Geogr. Univ. Zurich, 2007.

Skipper, Seabold and Perktold, J.: Statsmodels: Econometric and Statistical Modeling with Python, , doi:10.25080/majora-92bf1922-011, 2010.

Slatyer, R. O.: The absorption of water by plants, Nature, 30(757), 7-9, doi:10.1038/030007b0, 1960.

Stiehl-Braun, P. A., Hartmann, A. A., Kandeler, E., Buchmann, N. and Niklaus, P. A.: Interactive effects of drought and $\mathrm{N}$ fertilization on the spatial distribution of methane assimilation in grassland soils, Glob. Chang. Biol., 17(8), 2629-2639, doi:10.1111/j.1365-2486.2011.02410.x, 2011.

Thornthwaite, C. W.: An Approach toward a Rational Classification of Climate, Geogr. Rev., 38(1), 55-94, doi:10.1097/00010694-194807000-00007, 1948.

Uclés, O., Villagarcía, L., Cantón, Y. and Domingo, F.: Microlysimeter station for long term nonrainfall water input and evaporation studies, Agric. For. Meteorol., 182-183, 13-20, doi:10.1016/j.agrformet.2013.07.017, 2013.

Vesala, T., Sevanto, S., Grönholm, T., Salmon, Y., Nikinmaa, E., Hari, P. and Hölttä, T.: Effect of Leaf Water Potential on Internal Humidity and $\mathrm{CO}_{2}$ Dissolution: Reverse Transpiration and Improved Water Use Efficiency under Negative Pressure., Front. Plant Sci., 8, 54, doi:10.3389/fpls.2017.00054, 2017.

Waggoner, P. E., Begg, J. E. and Turner, N. C.: Evaporation of dew, Agric. Meteorol., 6(3), 227-230, doi:10.1016/0002-1571(69)90007-7, 1969.

Wang, L., Kaseke, K. F., Ravi, S., Jiao, W., Mushi, R., Shuuya, T. and Maggs-Kölling, G.: Convergent vegetation fog and dew water use in the Namib Desert, Ecohydrology, 12(7), doi:10.1002/eco.2130, 2019.

Yates, D. J. and Hutley, L. B.: Foliar uptake of water by wet leaves of Sloanea woollsii, an Australian subtropical rainforest tree, Aust. J. Bot., 43(2), 157-167, doi:10.1071/BT9950157, 1995.

Zeeman, M. J., Hiller, R., Gilgen, A. K., Michna, P., Plüss, P., Buchmann, N. and Eugster, W.: Management and climate impacts on net $\mathrm{CO}_{2}$ fluxes and carbon budgets of three grasslands along an elevational gradient in Switzerland, Agric. For. Meteorol., 150(4), 519-530, doi:10.1016/j.agrformet.2010.01.011, 2010.

Zhang, J., Zhang, Y. ming, Downing, A., Cheng, J. hui, Zhou, X. bing and Zhang, B. chang: The influence of biological soil crusts on dew deposition in Gurbantunggut Desert, Northwestern China, J. Hydrol., 379(3-4), 220-228, doi:10.1016/j.jhydrol.2009.09.053, 2009.

Zhang, Q., Wang, S., Yue, P. and Wang, R.: A measurement, quantitative identification and estimation method(QINRW) of non-rainfall water component by lysimeter, MethodsX, 6, 2873-2881, doi:10.1016/j.mex.2019.11.012, 2019. 